Article

\title{
Investigating the Effects of Ultrasonic Frequency and Membrane Technology on Biodiesel Production from Chicken Waste
}

\author{
Seyyedeh Faezeh Mirab Haghighi ${ }^{1}$, Payam Parvasi ${ }^{1}$, Seyyed Mohammad Jokar ${ }^{1, *}$ and Angelo Basile ${ }^{2, *}$ \\ 1 Department of Chemical, Petroleum and Gas Engineering, Shiraz University of Technology, \\ Shiraz 71345, Iran; faezehmirab7@gmail.com (S.F.M.H.); parvasi@sutech.ac.ir (P.P.) \\ 2 Institute on Membrane Technology of the Italian National Research Council (CNRITM), Via Pietro Bucci, \\ Cubo $17 / C$ c/o University of Calabria, Rende 87036, CS, Italy \\ * Correspondence: jokar@sutech.ac.ir (S.M.J.); a.basile@itm.cnr.it (A.B.); Tel.: +987-137-354-500 (S.M.J.)
}

Citation: Haghighi, S.F.M.; Parvasi,

P.; Jokar, S.M.; Basile, A. Investigating the Effects of Ultrasonic Frequency and Membrane Technology on Biodiesel Production from Chicken Waste. Energies 2021, 14, 2133. https://doi.org/10.3390/en14082133

Academic Editors: Attilio Converti and João Fernando Pereira Gomes

Received: 19 February 2021

Accepted: 7 April 2021

Published: 11 April 2021

Publisher's Note: MDPI stays neutral with regard to jurisdictional claims in published maps and institutional affiliations.

Copyright: (C) 2021 by the authors Licensee MDPI, Basel, Switzerland. This article is an open access article distributed under the terms and conditions of the Creative Commons Attribution (CC BY) license (https:// creativecommons.org/licenses/by/ $4.0 /)$.

\begin{abstract}
In this study, the experiments were carried out under different operating conditions to evaluate the effect of ultrasound waves on biodiesel production from chicken feet oil. A two-step esterification-transesterification mechanism was employed to improve the biodiesel quality. The continuous (methanol-to-oil molar ratio and $\mathrm{KOH}$ catalyst amount) and discrete (frequencies, 25 and $45 \mathrm{kHz}$ ) variables were investigated using the experimental design method. The five-level threefactor response surface method (RSM) was assisted to optimize the biodiesel synthesis variables. Applying RSM based on the central composite design (CCD), a polynomial equation was fitted to the experimental data with the aid of Design-Expert software. The model accuracy was checked by analysis of variance (ANOVA). The results showed the highest yield of $89.74 \%$ could be achieved by using an $\mathrm{M} / \mathrm{O}$ molar ratio of 12 , a $\mathrm{KOH}$ concentration of $1 \mathrm{wt} \%$, and an ultrasound frequency of $45 \mathrm{kHz}$. Finally, a mathematical model of biodiesel production in a membrane system was developed. The reaction rate constant was calculated as a function of ultrasonic frequency. Compared with the conventional method, the membrane system has significantly improved chicken feet biodiesel production's reaction rate. The membrane is more effective at higher frequencies than at lower ones.
\end{abstract}

Keywords: biodiesel production; ultrasound; chicken feet oil; response surface method; the membrane system

\section{Introduction}

One of societies' major issues is their need for fossil fuels and the continuing pollution growth due to their consumption. Diesel fuel is the greatest energy-dense transportation fuel, which causes many environmental problems such as air pollutant emissions and climate change [1,2]. Therefore, the economic output of petroleum products will decrease in the future. Considering these problems, researchers have been interested in alternative fuels [3]. Biodiesel is a green fuel produced from renewable sources [4]. It has several benefits compared with fossil fuels:

1- It has a renewable energy source.

2- It is nontoxic and decomposable.

3- It contains less pollutants (no sulfur).

4- It has lower toxic gas emissions.

5- It is relatively nonflammable due to its high ignition point [5].

Biodiesel production from animal fat and vegetable oil could enhance the fuel viscosity and combustion characteristics [6]. Therefore, it could be applied in typical diesel engines without modifications [7]. The most critical concern for biodiesel generation is the selection of suitable raw material. 
The main processes to produce biodiesel are determined by measuring the amount of free fatty acid (FFA) in the primary oil. The yield of biodiesel decreases by increasing the FA value of oil by more than $0.5-3 \%$. Therefore, an acid-catalyzed homogeneous esterification process should be done to decrease the oil FA content before the transesterification reaction [8,9]. Conventionally, the catalyzed transesterification process is utilized to generate biodiesel in a batch reactor equipped with a mechanical mixer [8].

Recently, ultrasonic waves had been introduced as the most effective method to improve the yield of a chemical reaction [10]. These waves produce mechanical vibrations when they are radiated to a liquid or solid [11,12]. When the mixture is subjected to ultrasound, the collision of the ultrasound with the reactants causes the formation of microbubbles, which produces an elevated local pressure [13]. This process involves creating, gradually growing, and ultimately bursting series of bubbles by applying ultrasound, generating a shock wave [14]. The shock wave energy is used to break covalent bonds and homogenize and perform some chemical reactions, especially nanoparticle synthesis and organic matter synthesis. The bursting of bubbles also releases energy locally and allows the chemical reaction to occur, which is called cavitation [15]. Therefore, an emulsion of oil and alcohol is formed which provides a large surface area for the reaction and causes the reduction of reaction time [16]. As a result, under ultrasonic mixing, the reaction carries on more rapidly than under mechanical stirring.

Alkaline sodium hydroxide and potassium hydroxide are the most commonly used catalysts for biodiesel production [17]. These catalysts can catalyze the reaction with low temperature and atmospheric pressure. Also, they can achieve high conversion rates in the shortest possible time [17]. Reports indicate that the alkaline-catalyzed transesterification reaction rate is about 4000 times faster than that with the acid catalyst [18].

Jian-Xun et al. (2007) [5] used acid catalysts for biodiesel generation from waste oil feedstocks. Due to the high FFA in the oil, a two-step (esterification-transesterification) process was used. The waste oil and propanol with a molar ratio of 3:1 were reacted in an ultrasonic bath with a power of $100 \mathrm{w}$, a frequency of $28 \mathrm{kHz}$, and at a temperature of $40-45^{\circ} \mathrm{C}$. The biodiesel yield of $94.86 \%$ was achieved in $50 \mathrm{~min}$, which was very high compared with the conventional method (84.43\%). Kelkar et al. [19] investigated the use of cavitation for the acceleration of the biodiesel synthesis process. The transesterification reaction with methanol was done in the presence of a sulfuric acid catalyst in an ultrasonic reactor. The results showed that a high conversion of $90 \%$ could be obtained at ambient operating conditions. It clearly illustrated the impact of cavitation phenomena as an excellent way to enhance the biodiesel production process.

Teixeira et al. (2009) [20] performed a comparison of the transesterification reaction in conventional and ultrasound-assisted $(20 \mathrm{kHz}$ and $400 \mathrm{~W})$ reactors. It was observed that the ultrasound-assisted reactor could significantly reduce the reaction time and increase the yield of biodiesel production. Santos et al. (2009) [21] produced biodiesel from soybean oil using an ultrasonic bath. As a result, a conversion yield of $91.8 \%$ was obtained within $30 \mathrm{~min}$. In another study, they investigated biodiesel production from tilapia fish oil through a low-frequency $(40 \mathrm{kHz})$ ultrasonic device with a power of $60 \mathrm{~W}$ at $30^{\circ} \mathrm{C}$ [22]. The response surface method (RSM) was utilized to evaluate the biodiesel yield at different operating conditions. They concluded that the most important factor for biodiesel production in an ultrasonic reactor was the alcohol-to-oil molar ratio. Yin et al. (2015) [23] performed experiments on soybean oil using ultrasound waves, resulting in an esterification efficiency of $96.1 \%$. Singh et al. (2017) [24] worked on the production of biodiesel from algae oil. The higher conversion was attained by the ultrasonic method (98\%) compared with the simple transesterification process (91\%). Suryanto et al. [25] investigated the process of transesterification to produce biodiesel from cottonseed oil in an ultrasonic device. Ultrasound technology has been revealed to decrease the reaction time and the amount of essential catalyst and alcohol needed for the reaction.

Various edible oils have been applied in biodiesel production, such as rapeseed, sunflower, soybean, and palm oil. However, these edible oil feedstocks are not economical 
due to their wide applications in the food industry. Therefore, nonedible oils, waste animal fats, and waste cooking oils have been considered as potential sources for biodiesel production [26-28].

Gole et al. [29] performed experiments to produce biodiesel from nonedible oils. In their study, the advantages of using an ultrasonic device were discussed. It was concluded that it is possible to produce biodiesel with the ultrasonic technique at a lower temperature and time than the mechanically agitated systems. Moreover, the decreased reaction temperature results in energy consumption reduction in biodiesel fabrication.

Choudhury et al. (2014) [30] conducted studies on biodiesel production from Jatropha oil. Jatropha is recognized as one of the most prominent herbs. The product is produced by esterification with a sulfuric acid catalyst and transesterification with calcium oxide catalyst. They found that the highest yield could be obtained with the catalyst concentration of $5.5 \mathrm{wt} \%$ and alcohol-to-oil molar ratio of 11 .

The production cost of virgin vegetable oils is higher than that of animal fats. Therefore, the feedstock costs for biodiesel can be reduced by using animal fats [31]. Animal fats such as tilapia fish [22], chicken skin [32], beef, and sheep tallow [33,34] are used for biodiesel production.

Abid et al. [32] began to produce biodiesel by extracting oil from chicken waste. The esterification process's optimum conditions were the methanol-to-oil (M/O) molar ratio of (3:1) and $1 \mathrm{wt} \%$ of catalyst concentration at $65^{\circ} \mathrm{C}$. Also, excellent catalytic performance was observed in the transesterification reaction at $60^{\circ} \mathrm{C}$.

One of the disadvantages of common technologies in biodiesel production is high methanol consumption due to the reversible reaction of the transesterification process [35,36]. Therefore, the reaction time and production cost increase in conventional systems. Another disadvantage is the significant loss of unreacted alcohol and water during the biodiesel purification [37]. In order to offset these drawbacks, the membrane technique is proposed as a promising modification method [36]. Membranes are widely employed for the separation of an individual component (e.g., hydrogen, $\mathrm{CO}_{2}, \mathrm{CH}_{4}, \mathrm{H}_{2} \mathrm{~S}$, etc.) from gas mixtures [38-42]. For biodiesel production, the membrane is used for the selective separation of biodiesel as a liquid product. Biodiesel permeates through the membrane, and the unpermitted components (especially alcohol) are recycled back to the reactor. Furthermore, biodiesel purification by membrane could decrease water consumption and increase fuel quality [43-45].

Sokac et al. [37] worked on polymeric membranes for biodiesel purification. The membranes included polyethersulfone, polyacrylonitrile, polypropylene, and regenerated cellulose. They showed that the polyacrylonitrile membrane could have a good performance in separating biodiesel produced by lipase-catalyzed transesterification [37]. Alves et al. [46] used a $30 \mathrm{kDa}$ membrane for biodiesel purification. Higher permeations were achieved at higher pressures in membranes with greater pore sizes. They concluded that membrane technology is a suitable alternative for biodiesel purification [46].

Poly(ether sulfone) hollow fiber membranes (PES-HFM) were selected as a membrane in work prepared by Noriega [47]. The process was experimentally tested and modeled $[47,48]$. Results showed that high-quality biodiesel could be obtained in a membrane reactor. The purity was 10 times more than the conventional reactor [48].

Talaghat et al. [49] modeled a continuous membrane tubular reactor used for biodiesel generation in the presence of an alkaline catalyst. They compared membrane and conventional reactors. The highest conversion was achieved in a membrane reactor with a methanol/oil ratio of 24 [49].

Cao et al. [50,51] used filtanium ceramic membrane for canola oil biodiesel purification. The retentate was recycled into the reactor. High-purity biodiesel was produced in their work.

In another work, they modeled the process and evaluated the reaction rate constants [52]. $\mathrm{NaOH}$ catalyst with different weight percents $(0.05,0.1$, and $0.5 \mathrm{wt} \%)$ and a 
methanol/oil ratio of 24:1 were used in their work. They showed that the application of membrane technology could increase the reaction rate.

As mentioned, there is no study on the effect of ultrasonic baths with different frequencies on biodiesel production from animal fat oil. This study aims to investigate the effect of the $\mathrm{M} / \mathrm{O}$ molar ratio, catalyst concentration, and ultrasonic frequency on the production of chicken feet oil biodiesel. In the following, the appropriate model was selected to optimize the operating conditions and efficiency of biodiesel production by central composite design (CCD), which is one of the subsets of the response surface methodology (RSM) method. In the following, a membrane system is proposed and modeled to increase the process's time consumption.

\section{Materials, Methods, and Analysis}

\subsection{Materials and Methods}

Materials

Chicken feet oil is the raw material used for biodiesel production. The chicken feet were placed in a dish, and some warm water was added, brought to boil, and simmered for $4-5 \mathrm{~h}$ [53]. The prepared liquid was cooled to a temperature at which it converted into solid and liquid phases. The solid fraction (oil) was then separated from the liquid. Table 1 shows some characteristics of the prepared chicken feet oil. The acid number and FFA content of the chicken feet oil were measured as $3 \mathrm{mg} \mathrm{KOH} / \mathrm{g}$ and $1.5 \%$, respectively.

Table 1. Characteristics of chicken feet oil.

\begin{tabular}{cc}
\hline \multicolumn{2}{c}{ Chicken Feet Oil } \\
\hline Acid Value & $3 \mathrm{mg} \mathrm{KOH} / \mathrm{g}$ \\
FFA & $1.5 \%$ \\
Boiling Point & $>220^{\circ} \mathrm{C}$ \\
\hline
\end{tabular}

It is worth mentioning that sulfuric acid and potassium hydroxide were employed as catalysts for the esterification and transesterification processes. Methanol was chosen as the alcohol for biodiesel production [2].

\subsection{Experimental Setup}

Figure 1 shows a schematic of the experimental setup. The Elma ultrasonic bath model TI-H5 was applied for biodiesel synthesis. The ultrasound device could operate with two frequencies (25 kHz and $45 \mathrm{kHz}$ ), sound power level up to $100 \mathrm{~W}$, and the temperature range up to $70{ }^{\circ} \mathrm{C}$. The reaction took place in a triple-neck flask equipped with condenser reflux (for returning the condensed alcohol vapor to the reactor), mechanical stirrer (at $500 \mathrm{rpm}$ ), and a digital thermometer (German Model 1048.30 TFA).

A hydrostatic weighing digital balance (AND model HR-200, $0.1 \mathrm{mg}$ sensitivity) and a centrifuge (TL 320 model) were used to weigh samples and separate glycerol from biodiesel, respectively.

The gas chromatography analysis was applied to reveal fatty acid compositions in the biodiesel. The Agilent 6890 GC was connected to an MS detector. The GC method conditions were as follows:

- Carrier gas: $\mathrm{He}, 99 / 999 \%$

- Constant column flow: $1.0 \mathrm{~mL} / \mathrm{min}$

- Injector temperature: $280^{\circ} \mathrm{C}$, split ratio: 1:100

- GC column: Varian, VF-1MS

- Column length: $30 \mathrm{~m}$

- Inside diameter: $0.25 \mathrm{~mm}$

- Film thickness: 0.25 micrometer 


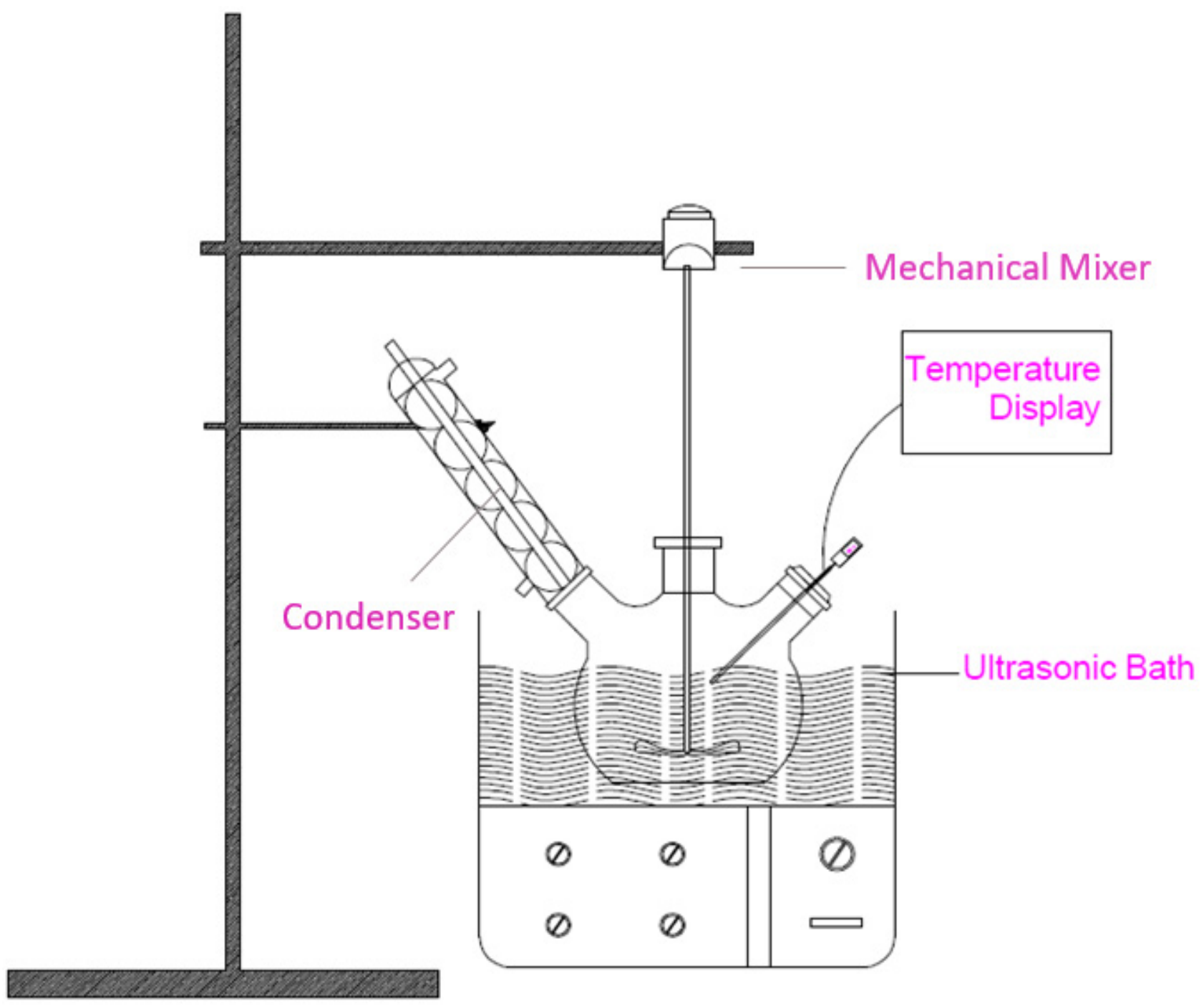

Figure 1. Schematic of experimental setup.

\subsection{Experimental Protocol}

Due to the high percentage of FFAs in chicken feet oil (Table 1), a two-step esterificationtransesterification mechanism should be considered to improve biodiesel quality. The esterification procedure was handled based on the research of Alptekin and Canakci [8]. In order to investigate the effectiveness of the ultrasound system, the reactions were performed in an ultrasonic water bath with two frequencies ( 25 and $45 \mathrm{kHz}$ ).

\subsubsection{Esterification}

Esterification of oils and fats is one of the advanced techniques used to modify glycerides' basic structure. As mentioned, this process should be performed for the oils with high FA content ( 0.5 to $5 \%$ by mass) [32]. The esterification reaction was performed for the prepared chicken feet oil with $1.5 \%$ FA. The reaction was catalyzed by $\mathrm{H}_{2} \mathrm{SO}_{4}$ to convert FFAs to methyl ester.

The esterification process was performed with $6: 1 \mathrm{M} / \mathrm{O}$ molar ratio, $1 \mathrm{wt} \%$ of catalyst concentration, $1 \mathrm{~h}$ reaction time, and $60^{\circ} \mathrm{C}$ reaction temperature in a $25 \mathrm{kHz}$ ultrasonic system. The produced mixture was kept in a funnel overnight to separate oil from water and alcohol. Figure 2 shows the photo of a prepared sample placed in a separating funnel. The yellow phase represents the esterified oil and the colorless phase represents the separated water. Afterward, the esterified oil was heated $\left(110^{\circ} \mathrm{C}, 1 \mathrm{~h}\right)$ to evaporate standing water and alcohol [8]. 


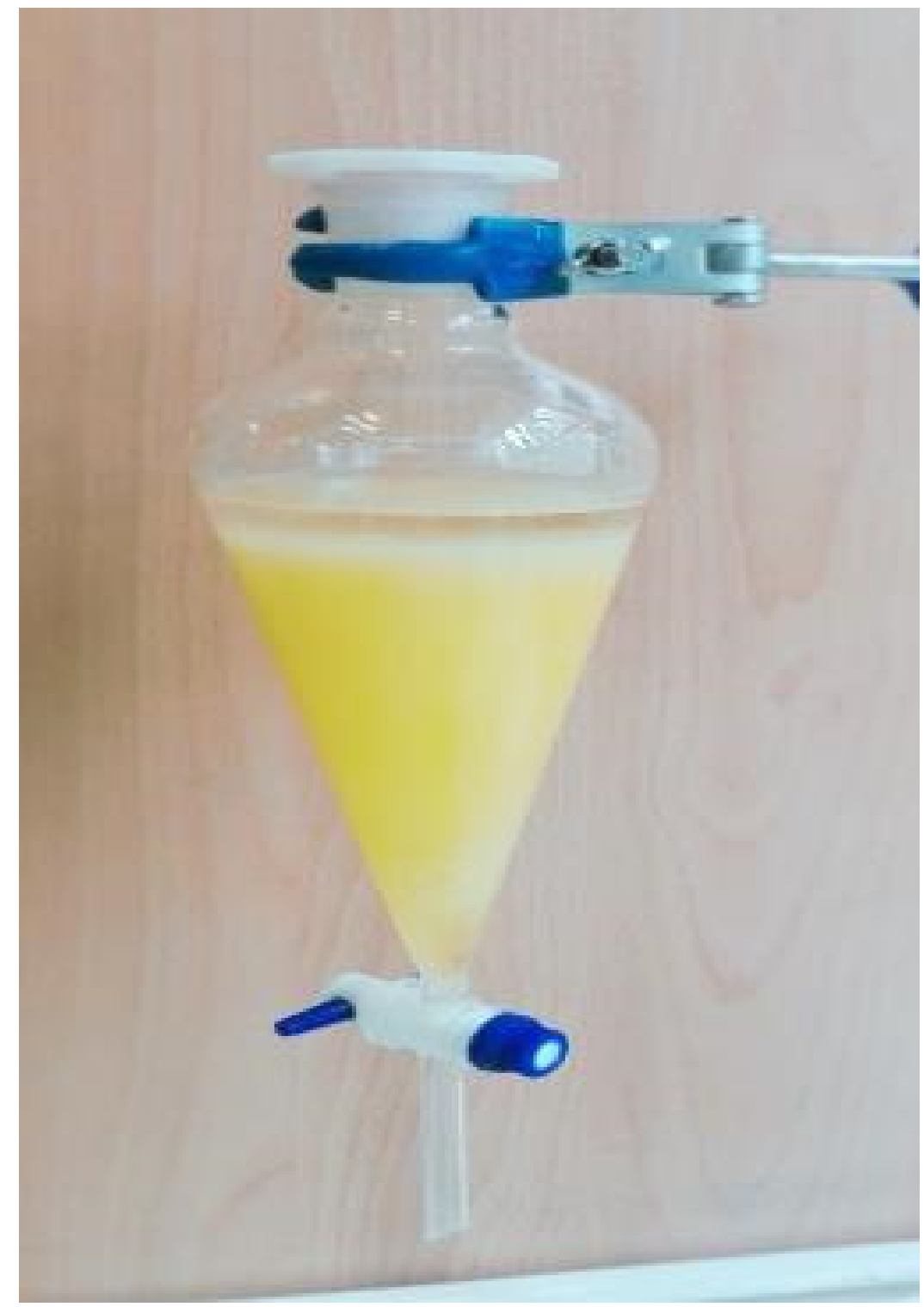

Figure 2. A prepared sample placed in separating funnel after the esterification process.

\subsubsection{Transesterification Reaction}

The flask was filled with prepared oil from the esterification process, methanol (3:115:1 M/O molar ratios), and $\mathrm{KOH}(0.5$ to $2.5 \mathrm{wt} \%)$. The reaction was carried out at $60{ }^{\circ} \mathrm{C}$, $500 \mathrm{rpm}$ mechanical agitation, and a reaction time of $1.5 \mathrm{~h}$ in an ultrasonic system with $25 \mathrm{kHz}$ and $45 \mathrm{kHz}$ frequencies. After the transesterification reaction, the produced mixture was centrifuged for $10 \mathrm{~min}$ at $2000 \mathrm{rpm}$ to separate glycerol and biodiesel layers. The obtained mixture was settled and the biodiesel was washed with distilled water. Afterward, the washed biodiesel was heated $\left(110^{\circ} \mathrm{C}\right)$ to eliminate the excess water and methanol [8]. Figure 3 shows an image of the produced sample placed in a separating funnel after the transesterification reaction. The yellow phase represents the produced biodiesel and the dark phase represents the glycerol. 


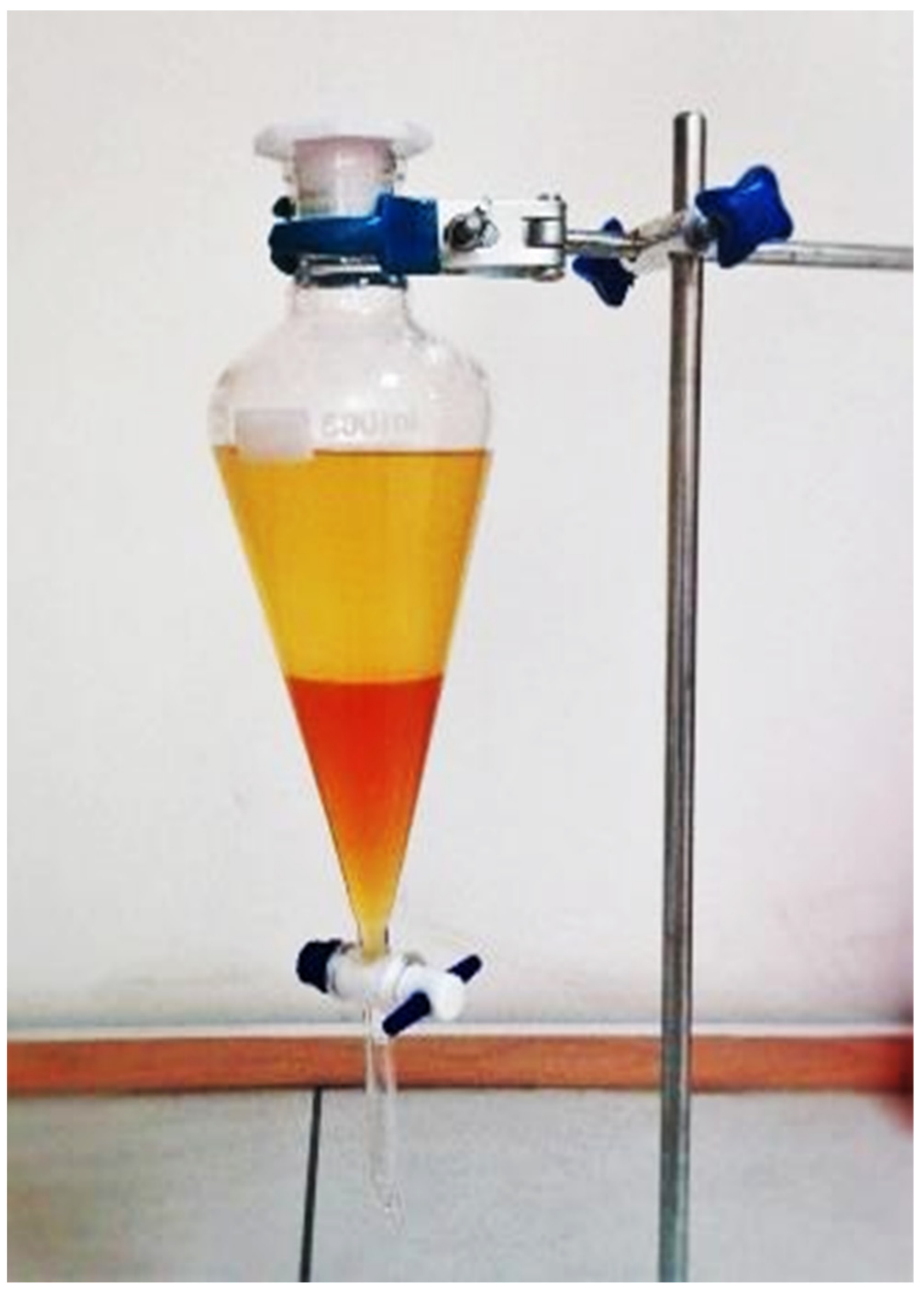

Figure 3. A mixture of methyl ester and glycerin after transesterification reaction.

The biodiesel yield could be calculated using the following formula [54]:

$$
\text { Yield }=\frac{\text { Total weight of methyl ester }}{\text { Total weight of oil in the sample }} \times 100
$$

\section{Results and Discussions}

\subsection{Experimental Design and Statistical Analysis}

The response surface methodology (RSM) comprises statistical techniques and applied mathematics used to model the processes based on the experimental data. The central composite design (CCD) approach-based response surface methodology (RSM) is used to optimize the response variable [53,55]. In this work, the Design-Expert software was utilized to design, analyze, and optimize the production process. The process variables, as well as the pertinent levels for CCD, are listed in Table 2. Two continuous variables (M/O molar ratio and catalyst amount) and one discrete variable (frequency) were considered. 
Table 2. Factors and their levels for CCD.

\begin{tabular}{ccccccc}
\hline \multirow{2}{*}{ Variable } & \multirow{2}{*}{ Symbol } & \multicolumn{5}{c}{ Coded Factor Level } \\
\cline { 3 - 7 } & & $\mathbf{- 2}$ & $\mathbf{- 1}$ & $\mathbf{0}$ & $\mathbf{1}$ & $\mathbf{2}$ \\
\hline Methanol-to-oil molar ratio & $\mathrm{A}$ & 3 & 6 & 9 & 12 & 15 \\
Catalyst amount $(\mathrm{wt} \%)$ & $\mathrm{B}$ & 0.5 & 1 & 1.5 & 2 & 2.5 \\
Frequency $(\mathrm{kHz})$ & $\mathrm{C}$ & & 25 & & 45 & \\
\hline
\end{tabular}

The five-level three-factor RSM (Table 2) was applied to optimize the transesterification reaction parameters. Totally, 20 experiments were performed to evaluate the effect of the variables on biodiesel yield.

The Design-Expert software proposed the following polynomial model as the best fitting to experimental results:

$$
\begin{gathered}
Y^{\chi}(x)=\beta_{0}+\sum_{i=1}^{n} \beta_{i} x_{i}^{4}+\sum_{i j(i<j)}^{n} \beta_{i j} x_{i}^{3} x_{j}+ \\
\sum_{i j(i<j)}^{n} \beta_{i} x_{i}^{2} x_{j}^{2}+\sum_{i j k(i<j<k)}^{n} \beta_{i j k} x_{i}^{2} x_{j} x_{k}+ \\
\sum_{i j k l(i<j<k<l)}^{n} \beta_{i j k l} x_{i} x_{j} x_{k} x_{l}
\end{gathered}
$$

where the parameters $Y, X_{i}, \beta_{0}, \beta_{i}, \beta_{i j}$, and $\chi$ stand for the response factor (fatty acid methyl ester (FAME) contents), the independent factor, the intercept, the first-order model coefficient, the coefficient for the interaction between $i$ and $j$, and power transform, respectively. The optimum value of $\lambda$ should be determined by the Box-Cox plot's minimum point [56]. Figure 4 illustrates the Box-Cox plot. As can be seen, the minimum occurred at $\lambda=3$.

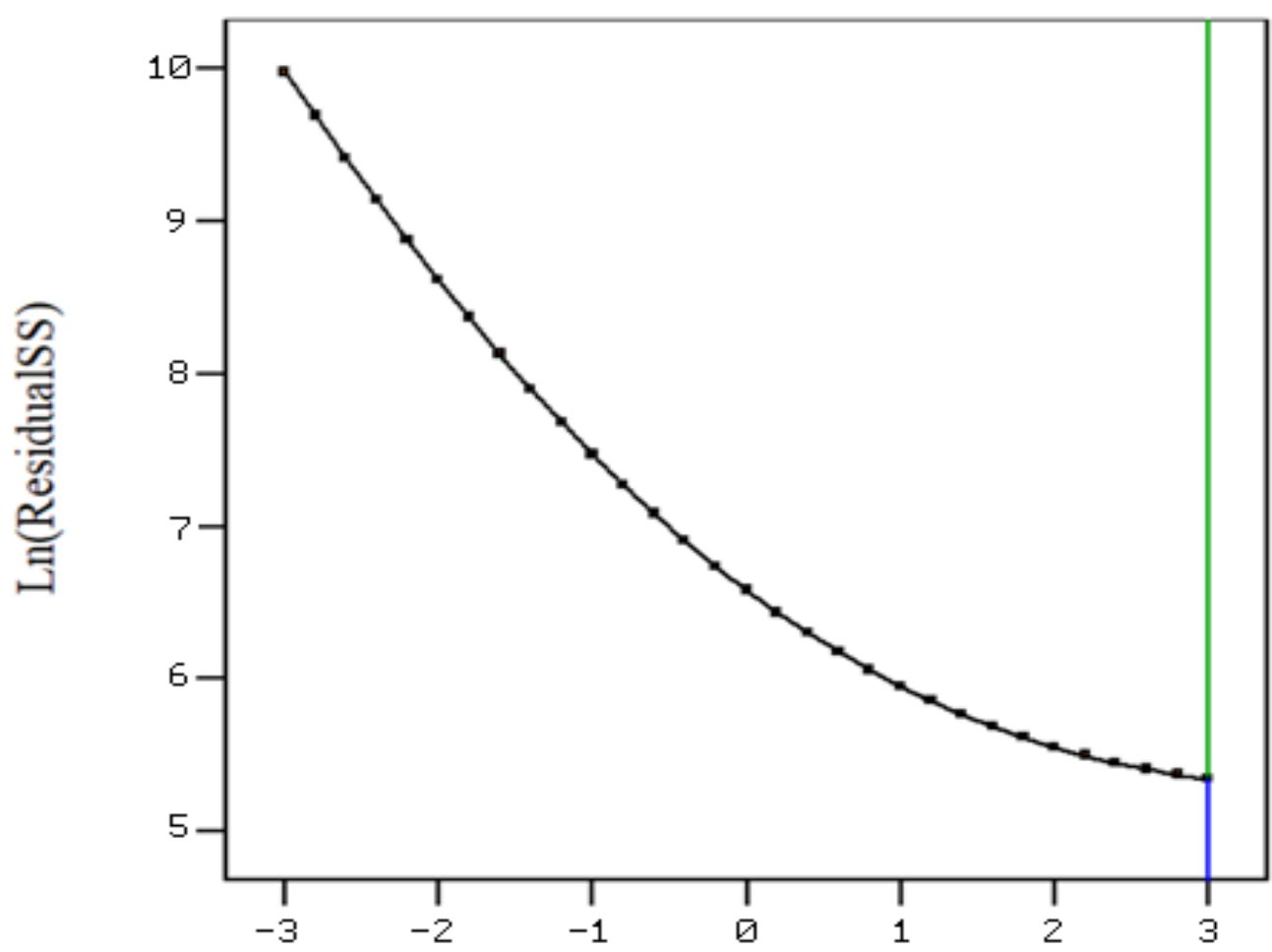

\section{Lambda}

Figure 4. Box-Cox plot for power transform.

The coefficients of Equation (2) were determined by the CCD approach for chicken feet oil biodiesel. Equation (3) is obtained in terms of coded values to estimate the biodiesel 
yield as a function of the M/O molar ratio (A), catalyst concentration (B), and frequency (C). The coded levels of variables are provided in Table 2.

$$
\begin{gathered}
(\text { yield })^{3}=489,700+9386.94 \times \mathrm{A}+14,241.49 \times \mathrm{B}-31,687.37 \times \mathrm{C} \\
-5383.10 \times \mathrm{A} \times \mathrm{B}-36,552.07 \times \mathrm{B} \times \mathrm{C}-67,519.76 \times \mathrm{A}^{2} \\
-52,651.12 \times \mathrm{B}^{2}-155,000 \times \mathrm{A}^{2} \times \mathrm{B}+10,427.46 \times \mathrm{A} \times \mathrm{B}^{2}+ \\
43,124.22 \times \mathrm{B}^{2} \times \mathrm{C}+141,600 \times \mathrm{A}^{2} \times \mathrm{B}^{2}
\end{gathered}
$$

Table 3 lists the results of the CCD experimental design matrix for the transesterifica-

\begin{tabular}{|c|c|c|c|c|}
\hline Factor 1 & Factor 2 & Factor 3 & Biodiesel Yield & Biodiesel Yield \\
\hline $\begin{array}{c}\text { A: Methanol: } \\
\text { Oil }\end{array}$ & $\begin{array}{c}\text { B: Catalyst } \\
(w t \%)\end{array}$ & $\begin{array}{c}\text { C: Frequency } \\
(\mathbf{k H z})\end{array}$ & Actual \% & Predicted \% \\
\hline 9:01 & 0.5 & 25 & 24.99 & 33.22 \\
\hline $6: 01$ & 2 & 25 & 69.99 & 72.5 \\
\hline $6: 01$ & 2 & 45 & 71.72 & 69.16 \\
\hline 9:01 & 2.5 & 25 & 63.77 & 62.14 \\
\hline $15: 01$ & 1.5 & 45 & 64.27 & 59.13 \\
\hline $6: 01$ & 1 & 25 & 83.92 & 83.33 \\
\hline 3:01 & 1.5 & 45 & 46.43 & 55.3 \\
\hline $15: 01$ & 1.5 & 25 & 59.56 & 64.64 \\
\hline 3:01 & 1.5 & 25 & 67.06 & 61.49 \\
\hline 9:01 & 2.5 & 45 & 70.86 & 72.13 \\
\hline 9:01 & 0.5 & 45 & 78.6 & 77.45 \\
\hline $12: 01$ & 1 & 45 & 88.52 & 89.84 \\
\hline $12: 01$ & 2 & 25 & 74.33 & 74.28 \\
\hline 9:01 & 1.5 & 25 & 80.16 & 80.49 \\
\hline $12: 01$ & 1 & 25 & 87.09 & 85.69 \\
\hline 9:01 & 1.5 & 45 & 71.63 & 77.08 \\
\hline $6: 01$ & 1 & 45 & 87.17 & 87.71 \\
\hline 9:01 & 1.5 & 45 & 82.6 & 77.08 \\
\hline $12: 01$ & 2 & 45 & 71.06 & 71.11 \\
\hline 9:01 & 1.5 & 25 & 80.03 & 80.49 \\
\hline
\end{tabular}
tion reaction. Clearly, a good consistency was seen between the actual response and the predicted values obtained from Equation (3).

Table 3. CCD experimental design matrix.

The analysis of variance (ANOVA) was employed to analyze the proposed response surface model (Table 4). The model accuracy was checked using the coefficient of determination $\left(\mathrm{R}^{2}\right)$, F-value, and $p$-value. Particularly, $\mathrm{R}^{2}$ should be close to unity. This proximity indicates a better correlation between the experiment and the predicted values. Besides, statistical significance was checked by calculating the F-value and $p$-value [57].

The model $p$-value (0.0014) and F-value (10.3) confirmed that the proposed model has statistical significance demonstrating the experiment's obtained results. Furthermore, the lack of fit with an F-value of 0.41 and a low $p$-value of 0.8334 shows that the lack of fit is not significant.

\subsection{Effect of Process Variables on Biodiesel Production}

The effect of catalyst amount, M/O molar ratio, and their reciprocal interaction on the synthesis of chicken feet biodiesel with the ultrasonic frequency of $25 \mathrm{kHz}$ are illustrated in Figure 5. The biodiesel yield is moderately influenced by the methanol/oil molar ratio at low catalyst concentration. Conversely, the impact of methanol/oil molar ratio is considerable at a high catalyst concentration. The maximum acquisition of FAME content is achieved with a high methanol/oil molar ratio and $1 \%$ of catalyst concentration $(w / w)$. 
Table 4. Analysis of variance (ANOVA) for the proposed response surface model.

\begin{tabular}{cccccc}
\hline Source & Sum of Squares & df & Mean Square & F Value & $p$ Value \\
\hline Model & $6.065 \times 10^{11}$ & 11 & $5.514 \times 10^{10}$ & 10.32 & 0.0014 \\
A: M: $\mathrm{O}$ & $1.41 \times 10^{9}$ & 1 & $1.41 \times 10^{9}$ & 0.26 & 0.6213 \\
B: Catalyst.C & $3.245 \times 10^{9}$ & 1 & $3.245 \times 10^{9}$ & 0.61 & 0.4582 \\
C: Frequency & $1.205 \times 10^{10}$ & 1 & $1.205 \times 10^{10}$ & 2.26 & 0.1715 \\
AB & $231,800,000$ & 1 & $231,800,000$ & 0.043 & 0.8402 \\
BC & $3.207 \times 10^{10}$ & 1 & $3.207 \times 10^{10}$ & 6 & 0.0399 \\
$\mathrm{~A}^{2}$ & $1.459 \times 10^{11}$ & 1 & $1.459 \times 10^{11}$ & 27.31 & 0.0008 \\
$\mathrm{~B}^{2}$ & $8.871 \times 10^{10}$ & 1 & $8.871 \times 10^{10}$ & 16.61 & 0.0036 \\
$\mathrm{~A}^{2} \mathrm{~B}$ & $1.282 \times 10^{11}$ & 1 & $1.282 \times 10^{11}$ & 24 & 0.0012 \\
$\mathrm{AB}^{2}$ & $5.799 \times 10^{8}$ & 1 & $5.799 \times 10^{8}$ & 0.11 & 0.7502 \\
$\mathrm{~B}^{2} \mathrm{C}$ & $8.034 \times 10^{10}$ & 1 & $8.034 \times 10^{10}$ & 15.04 & 0.0047 \\
$\mathrm{~A}^{2} \mathrm{~B}^{2}$ & $9.164 \times 10^{10}$ & 1 & $9.164 \times 10^{10}$ & 17.16 & 0.0032 \\
Residual & $4.273 \times 10^{10}$ & 8 & $5.342 \times 10^{9}$ & & 0.8334 \\
Lack of Fit & $2.351 \times 10^{10}$ & 6 & $3.919 \times 10^{9}$ & 0.41 & Not Significant \\
Pure Error & $1.922 \times 10^{10}$ & 2 & $9.609 \times 10^{9}$ & & \\
Cor Total & $6.493 \times 10^{11}$ & 19 & & & 0.9342 \\
Std.Dev & $73,086.43$ & & $\mathrm{R}^{2}$ & & 0.8437 \\
Mean & 402,100 & & Adjusted R & & \\
\hline
\end{tabular}

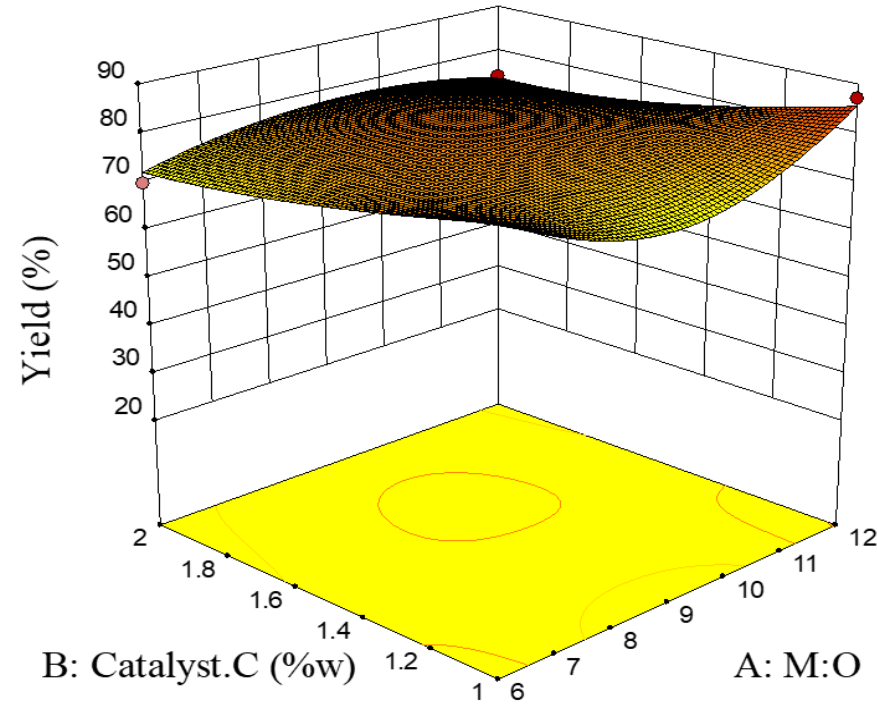

(a)

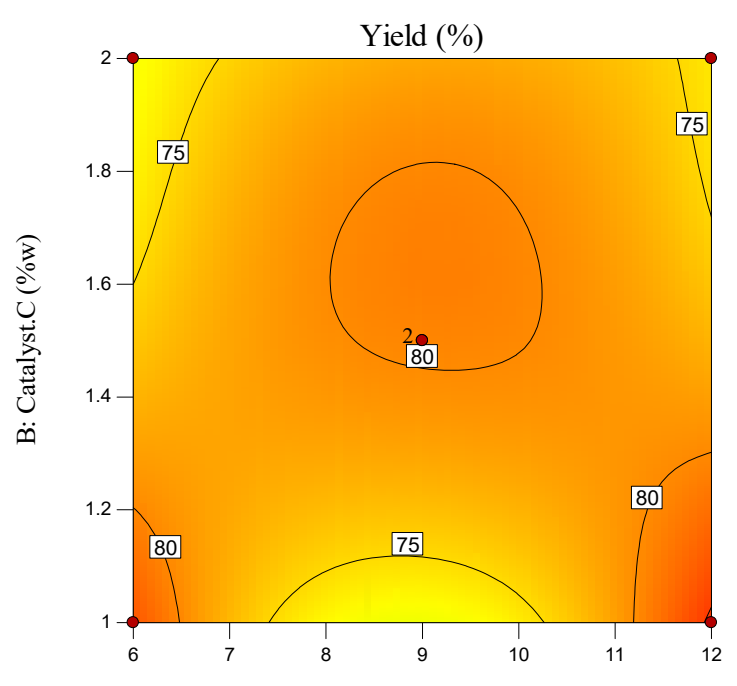

A: $\mathrm{M}: \mathrm{O}$

(b)

Figure 5. The effect of $\mathrm{KOH}$ catalyst amount, methanol-to-oil molar ratio, and their reciprocal interaction on chicken feet oil biodiesel synthesis using the $25 \mathrm{kHz}$ ultrasonic frequency, (a) response surface 3D plot, (b) contour plot.

The influence of $\mathrm{KOH}$ catalyst amount, $\mathrm{M} / \mathrm{O}$ molar ratio, and reciprocal interaction on chicken feet biodiesel synthesis using an ultrasonic frequency of $45 \mathrm{kHz}$ are shown in Figure 6. It could be observed that FAME content increases with a decrease in catalyst concentration and methanol/oil molar ratio. The highest methyl ester content is achieved with a catalysis level of $1 \mathrm{wt} \%$ and an oil/methanol molar ratio of 1:12. 


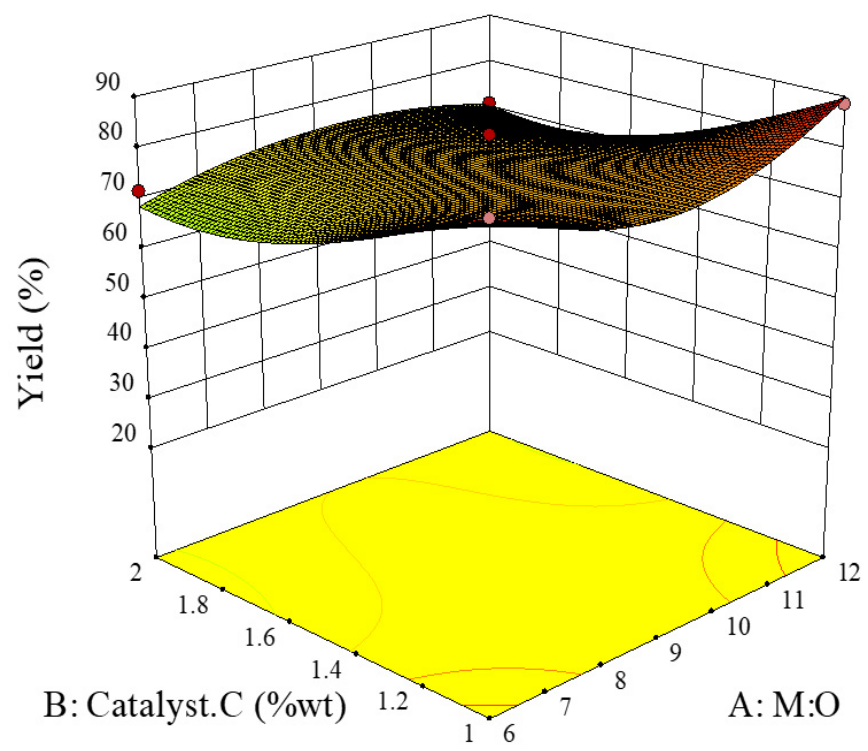

(a)

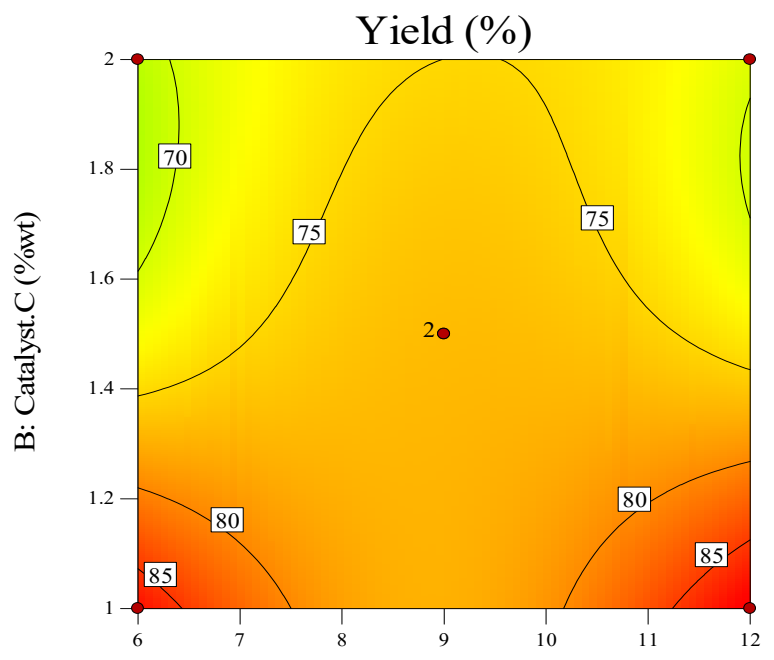

A: M:O

Figure 6. The effect of $\mathrm{KOH}$ catalyst amount, methanol-to-oil molar ratio, and their reciprocal interaction on chicken feet biodiesel synthesis using the $45 \mathrm{kHz}$ ultrasonic frequency, (a) response surface 3D plot, (b) contour plot.

The comparison between the results of Figures 5 and 6 shows that the higher frequency $(45 \mathrm{kHz})$ could give an increased yield of biodiesel at lower catalyst amount.

\subsection{Optimization}

The optimum value of the response surface, catalyst amount, and M/O molar ratio were obtained by considering the desirability function approach as presented in Figure 7. The results showed that the maximum yield of $89.74 \%$ could be obtained with the catalyst amount of $1 \mathrm{wt} \%$, M/O molar ratio of 12:1, and ultrasonic frequency of $45 \mathrm{kHz}$.

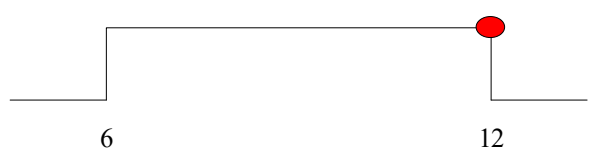

$\mathrm{A}: \mathrm{M}: \mathrm{O}=12$

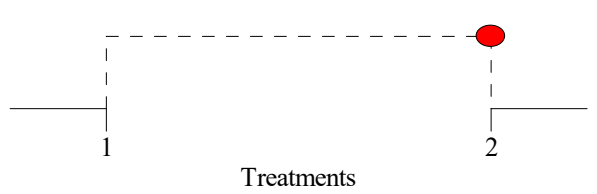

$\mathrm{C}:$ Frequency $=45$

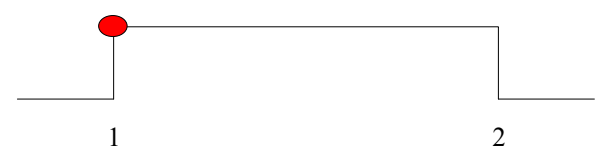

B:Catalyst. $\mathrm{C}=1$

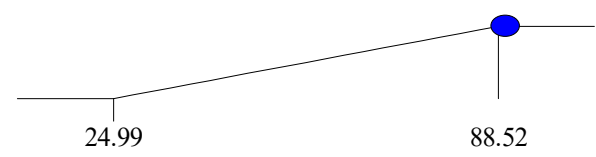

Yield $=89.7368$

Desirability $=1.000$

Figure 7. Desirability ramp of yield.

In order to check the validity of the results obtained by Figure 7, an experiment was set at these conditions. The experimental yield of mutton bone biodiesel was estimated as $89.74 \%$, which showed good consistency with the desirability function result $(90.14 \%)$. 


\section{Analysis}

A set of analyses was carried out to determine the biodiesel sample's properties with optimal conditions and compare the results with the standards.

\subsection{FA Contents}

The qualitative criteria of biodiesel and the acceptable impurity in it are determined by the standards [58]. For instance, the maximum allowable methyl ester content in a biofuel is about $5 \mathrm{mg} / \mathrm{kg}$ (ppm) in the transport sector.

In order to determine FAs composition in biodiesel, the GC analysis was performed. The analysis was carried out using the library of the National Institute of Standards and Technology (NIST) with more than 62,000 patterns (Figure 8).

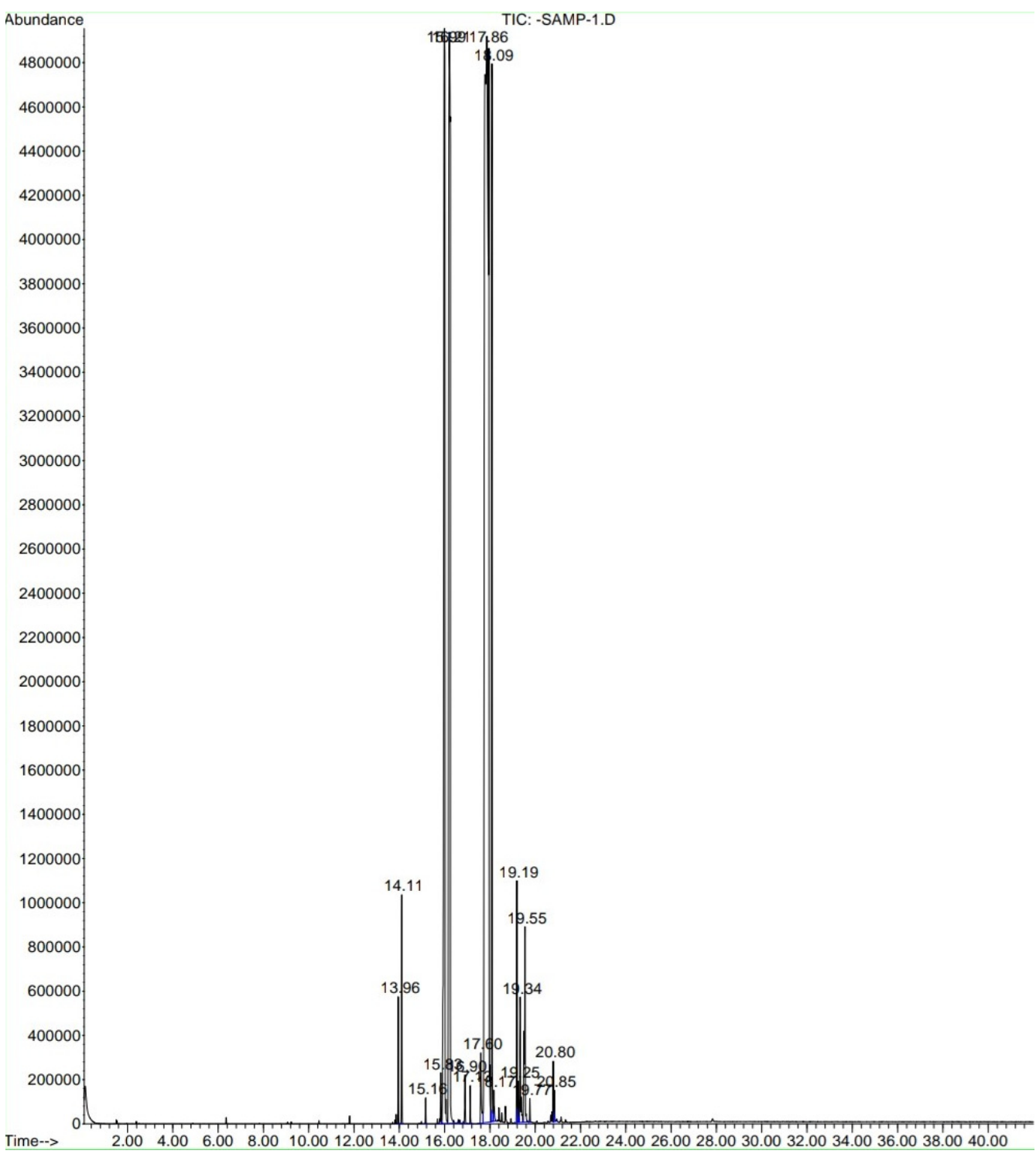

Figure 8. GC/MS chromatogram of the biodiesel from chicken feet oil.

As illustrated in Figure 9, GC/MS chromatogram analysis of biodiesel had 18 peaks with retention time ranging from 13.95 to $20.85 \mathrm{~min}$. As shown, the presence of phytochemicals is clear. Totally, 18 FAME compounds were determined in the chicken feet oil biodiesel (Table 5). Elaidic acid (47.98\%), palmitic acid $(19.18 \%)$, and palmitoleic acid $(16.45 \%)$ were the three main ingredients. 


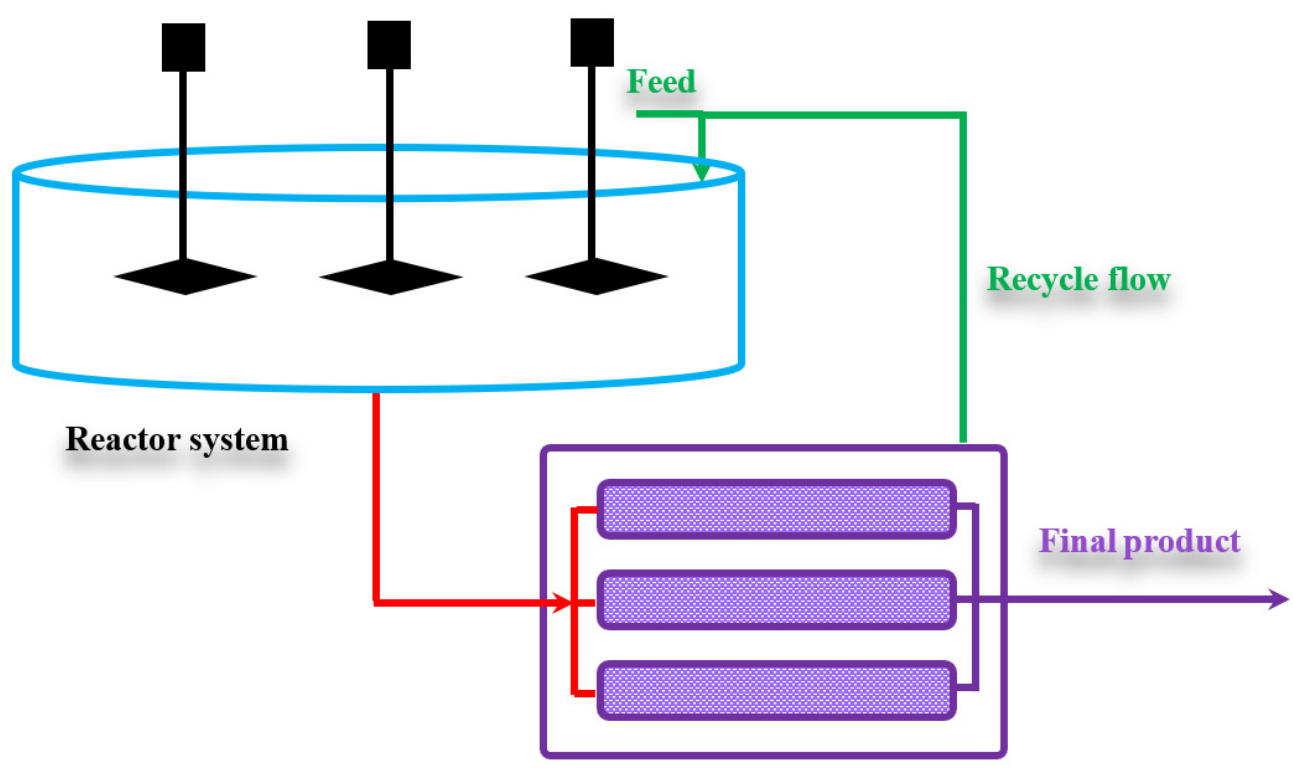

Membrane module

Figure 9. Schematic of the membrane reactor membrane system.

Table 5. FAME composition of chicken feet oil biodiesel.

\begin{tabular}{cccc}
\hline $\begin{array}{c}\text { Retention Time } \\
\text { (min) }\end{array}$ & $\begin{array}{c}\text { Identified Compounds } \\
\text { (Methyl + Acid) }\end{array}$ & \% & Type of FA \\
\hline 14.11 & Tetradecanoic acid & 1.13 & Saturated \\
15.16 & Pentadecanoic acid & 0.13 & Saturated \\
15.83 & 7,10-Hexadecadienoic acid & 0.32 & Unsaturated \\
15.99 & 9-Hexadecenoic acid (Palmitoleic acid) & 16.45 & Unsaturated \\
16.21 & Hexadecanoic acid (Palmitic acid) & 19.18 & Saturated \\
16.9 & 9-Octadecenoic acid (z) (Oleic acid) & 0.36 & Unsaturated \\
17.14 & Heptadecanoic acid (Margaric acid) & 0.2 & Saturated \\
17.6 & 6,9,12-Octadecatrienoic acid (Linolenic acid) & 0.65 & Unsaturated \\
17.86 & 9-Octadecenoic acid (Elaidic acid) & 47.98 & Unsaturated \\
18.09 & Octadecanoic acid (Stearic acid) & 8.14 & Saturated \\
18.17 & 9,12-Octadecadienoic acid (Linolelaidic acid) & 0.28 & Unsaturated \\
19.19 & 5,8,11,14-Eicosatetraenoic acid & 1.28 & Unsaturated \\
19.25 & 5,8,11-Eicosatrienoic acid & 0.3 & Unsaturated \\
19.34 & 7,10,13-Eicosatrienoic acid & 1.04 & Unsaturated \\
19.55 & 11-Eicosenoic acid & 1.89 & Unsaturated \\
19.77 & Eicosanoic acid (Arachidic acid) & 0.13 & Saturated \\
20.8 & Methyl Arachidonate & 0.33 & Unsaturated \\
20.85 & Cyclooctene,3-ethenyl & 0.22 & Saturated \\
\hline
\end{tabular}

Clearly, there were seven saturated FAs such as methyl tetradecanoic acid (1.13\%), methyl pentadecanoic acid $(0.13 \%)$, methyl hexadecanoic acid $(19.18 \%)$, methyl heptadecanoic acid $(0.2 \%)$, methyl octadecanoic acid $(8.14 \%)$, methyl eicosanoic acid $(0.13 \%)$, and cyclooctene, 3-ethenyl (0.22\%). Moreover, 11 unsaturated FAs were found in the biodiesel.

\subsection{Physicochemical Characterization}

The properties of chicken feet oil biodiesel like density, acid value, saponification value, iodine value, cetane number, flash, fire, and cloud points were examined based on the ASTM standard procedures. The kinematic viscosity test was done based on ASTM D92-85 using a Canon-Fenske Routine Viscometer at $40{ }^{\circ} \mathrm{C}$. The standard values and experimental results are compared in Table 6. Clearly, the obtained values from the analysis 
are within the standard range. The findings support a good performance of biodiesel fuel prepared from chicken feet oil.

Table 6. Physiochemical properties of chicken feet oil biodiesel.

\begin{tabular}{|c|c|c|c|c|c|c|c|}
\hline Property & Unit & $\begin{array}{c}\text { Method } \\
\text { Used } \\
\text { (ASTM ... ) }\end{array}$ & $\begin{array}{c}\text { EN } \\
14214 \\
{[44]}\end{array}$ & $\begin{array}{c}\text { ASTM } \\
\text { D6751-10 } \\
{[43]}\end{array}$ & $\begin{array}{c}\text { ASTM } \\
6751-02 \\
{[4,45]}\end{array}$ & $\begin{array}{l}\text { Diesel } \\
\text { Fuel } \\
\text { ASTM } \\
\text { D975 }\end{array}$ & $\begin{array}{l}\text { Biodiesel } \\
\text { (This Study) }\end{array}$ \\
\hline Density (@ $\left.15^{\circ} \mathrm{C}\right)$ & $\mathrm{g} / \mathrm{cm}^{3}$ & D4052-91 & $0.86-0.90$ & - & $0.87-0.9$ & 0.85 & 0.872 \\
\hline Acid value & $\mathrm{mg} \mathrm{KOH} / \mathrm{g}$ & - & $0.5 \max$ & $0.5 \max$ & - & 0.5 & 0.56 \\
\hline $\begin{array}{l}\text { Saponification } \\
\text { value }\end{array}$ & $\mathrm{mg} / \mathrm{kg}$ & - & - & - & - & - & 190.74 \\
\hline Iodine value & $\mathrm{gI}_{2} / 100 \mathrm{~g}$ & - & $120 \max$ & - & - & 38.3 & 40.6 \\
\hline Cetane number & - & D613 & $51 \mathrm{~min}$ & $46-70$ & $47 \mathrm{~min}$ & $40-55$ & 65.78 \\
\hline Flash point & ${ }^{\circ} \mathrm{C}$ & D92-85 & $120 \mathrm{~min}$ & $130 \mathrm{~min}$ & $130 \mathrm{~min}$ & $52 \mathrm{~min}$ & 164 \\
\hline Fire point & ${ }^{\circ} \mathrm{C}$ & D92-85 & - & - & - & - & 184 \\
\hline Cloud point & ${ }^{\circ} \mathrm{C}$ & D2500-02 & - & - & -3 to 12 & - & 5 \\
\hline $\begin{array}{c}\text { Kinematic } \\
\text { viscosity }\left(@ 40^{\circ} \mathrm{C}\right)\end{array}$ & $\mathrm{mm}^{2} / \mathrm{s}$ & D92-85 & $3.5-5.0$ & $1.9-6.0$ & $1.9-6$ & - & 4.5 \\
\hline
\end{tabular}

\section{Modeling of Chicken Feet Biodiesel Production in a Membrane Reactor System}

In this section, attempts have been made to propose a membrane system to decrease the transesterification reaction time. The system has the potential to separate biodiesel (FAME) and recycle it to the reactor. Therefore, the biodiesel purification and reaction rate enhancement will take place simultaneously.

\subsection{Determination of the Reaction Kinetics}

The physical ultrasonic wave effects on reactants (methanol and triglyceride) are dissimilar. Thus, individual reaction rate orders should be taken into account for the reactants in the transesterification reaction. Equation (4) represents the general equation for the transesterification reaction. In this reaction, $[T G],[M],[P]$, and $[G]$ denote the triglyceride, methanol, biodiesel (FAME), and glycerol concentrations, respectively.

$$
T G+3 M \rightarrow P+G
$$

Grant and Gude [59] proposed the following reaction rate for ultrasonic transesterification reaction:

$$
r_{P}=\frac{d[P]}{d t}=k[T G]^{\gamma}[M]^{\delta}
$$

In this work, the reaction rate constant is considered as a function of ultrasonic bath frequency:

$$
k=\alpha \times f(\mathrm{kHz})+\beta
$$

The constants of Equations (5) and (6) are calculated based on the model fitting of experimental results and signified in Table 7.

Table 7. Statistical summary of variance analysis of the proposed model.

\begin{tabular}{cc}
\hline Parameter & Value \\
\hline$\alpha(\mathrm{L} / \mathrm{mol} \cdot \mathrm{min} \cdot \mathrm{kHz})$ & $9.500 \times 10^{-5}$ \\
$\beta(\mathrm{L} / \mathrm{mol} \cdot \mathrm{min})$ & $3.263 \times 10^{-2}$ \\
$\gamma$ & 1 \\
$\delta$ & 1 \\
\hline
\end{tabular}




\subsection{Mathematical Modeling of the Membrane Reactor System}

The diagram for the proposed membrane system is presented in Figure 9. The reactants containing methanol and triglyceride are fed in a well-stirred tank. The products are then directed to a membrane module. The biodiesel is permeated through the membrane to allow the recycling of the retentate (especially alcohol) to the reactor. This will lead to producing high-purity biodiesel as a final product. In this work, a filtanium ceramic membrane (TAMI, Nyons, France) made of titanium oxide support and the active layer was considered [51].

Equation (7) is used for estimating the kinetics of the ultrasound-assisted biodiesel production from chicken feet oil. In order to obtain this equation, a perfect mixture for the recycled stream is assumed, leading to the uniform properties (temperature, concentration, etc.) for the recycled stream. On the other hand, the feed mass flow rate is considered equal to the product mass flow rate [52].

$$
\dot{\mathrm{V}}_{\text {out }}=\frac{\dot{\mathrm{m}}_{\text {Total-in }}}{\rho_{\text {out }}}=\frac{F_{\text {Methanol-in }} \times M W_{\text {Methanol }}+F_{T G-\text { in }} \times M W_{T G}}{\rho_{\text {out }}}
$$

In Equation (7), $\dot{\vee}_{\text {out }}, \dot{\mathrm{m}}_{\text {Total-in }}, F_{\text {Methanol-in }}, F_{T G-i n}$, and $M W_{T G}, \rho_{\text {out }}$ are permeate flow rate of the $(\mathrm{L} / \mathrm{min})$, mass flow rate of the feedstock, methanol molar rate in the feed stream $(\mathrm{mol} / \mathrm{min})$, triglyceride molar rate in the feed stream $(\mathrm{mol} / \mathrm{min})$, triglyceride molecular weight $(\mathrm{g} / \mathrm{mol})$, and product density $(\mathrm{g} / \mathrm{mL})$, respectively.

The components molar balance is provided in the following. Triglyceride is supposed not to be presented in the reactor outlet stream. Hence, the molar accumulation rate of triglyceride is as follows:

$$
\frac{d(T G)}{d t}=F_{T G-i n}+r_{T G} \times V_{0}
$$

For FAME, glycerol, and methanol, the mole balances are presented in Equations (9)-(11).

$$
\begin{gathered}
\frac{d(F A M E)}{d t}=r_{F A M E} \times V_{0}-F_{F A M E-o u t} \\
\frac{d(G)}{d t}=r_{G} \times V_{0} \\
\frac{d(\text { Methanol })}{d t}=F_{\text {Methanol-in }}+r_{\text {Methanol }} \times V_{0}
\end{gathered}
$$

where:

$$
F_{F A M E-o u t}=[F A M E]_{\text {out }} \times \dot{\mathrm{V}}_{\text {out }}
$$

In Equations (8)-(14), $V_{0},[x], r, t, F_{x-\text { in }}$, and $F_{x \text {-out }}$ are reactor volume $(\mathrm{L})$, concentration of component $x(\mathrm{~mol} / \mathrm{L})$, reaction rate $((\mathrm{mol} / \mathrm{min}) / \mathrm{L})$, time $(t)$, and flowrate of component $x$ in feed and product streams $(\mathrm{mol} / \mathrm{min})$, respectively. Two distinct phases are assumed to be formed: methanol, glycerol, and FAME are presented in a single mobile phase and triglyceride is formed in another phase. The mobile phase volume $\left(V_{\text {mobile }}\right)$ can be calculated by Equation (13).

$$
V_{\text {mobile }}=V_{0}-\frac{[T G] \times V_{0} \times M W_{T G}}{\rho_{T G}}
$$

The concentration of FAME in the mobile phase passing through the membrane could be obtained from Equation (14).

$$
[F A M E]_{\text {out }}=\frac{V_{0} \times[F A M E]}{V_{\text {mobile }}}=\frac{[F A M E]}{\left(1-\frac{[T G] \times M W_{T G}}{\rho_{T G}}\right)}
$$

MATLAB 2016a software was applied for system modeling. The modified Rosenbrock method (ode23s) was assisted to solve the set of ODEs. 
Table 8 presents the system specifications for the membrane system. The system conditions are similar to those used for experimental tests.

Table 8. The operating parameters of the membrane reactor system.

\begin{tabular}{cc}
\hline Parameter & Value \\
\hline Initial concentration of TG (mole/L) & 0.8 \\
Initial concentration of methanol (mole/L) & 9.84 \\
Reactor volume $(\mathrm{L})$ & 80 \\
Reaction temperature $\left({ }^{\circ} \mathrm{C}\right)$ & 68 \\
\hline
\end{tabular}

\subsubsection{Model Validation}

At first, the model validation is checked by experimental data obtained from Cao et al.'s work [52]. They produced biodiesel from canola oil using a $6 \mathrm{~L}$ membrane reactor system [52]. Figure 10 shows the comparison of experimental and calculated FAME concentration variation in the membrane reactor.

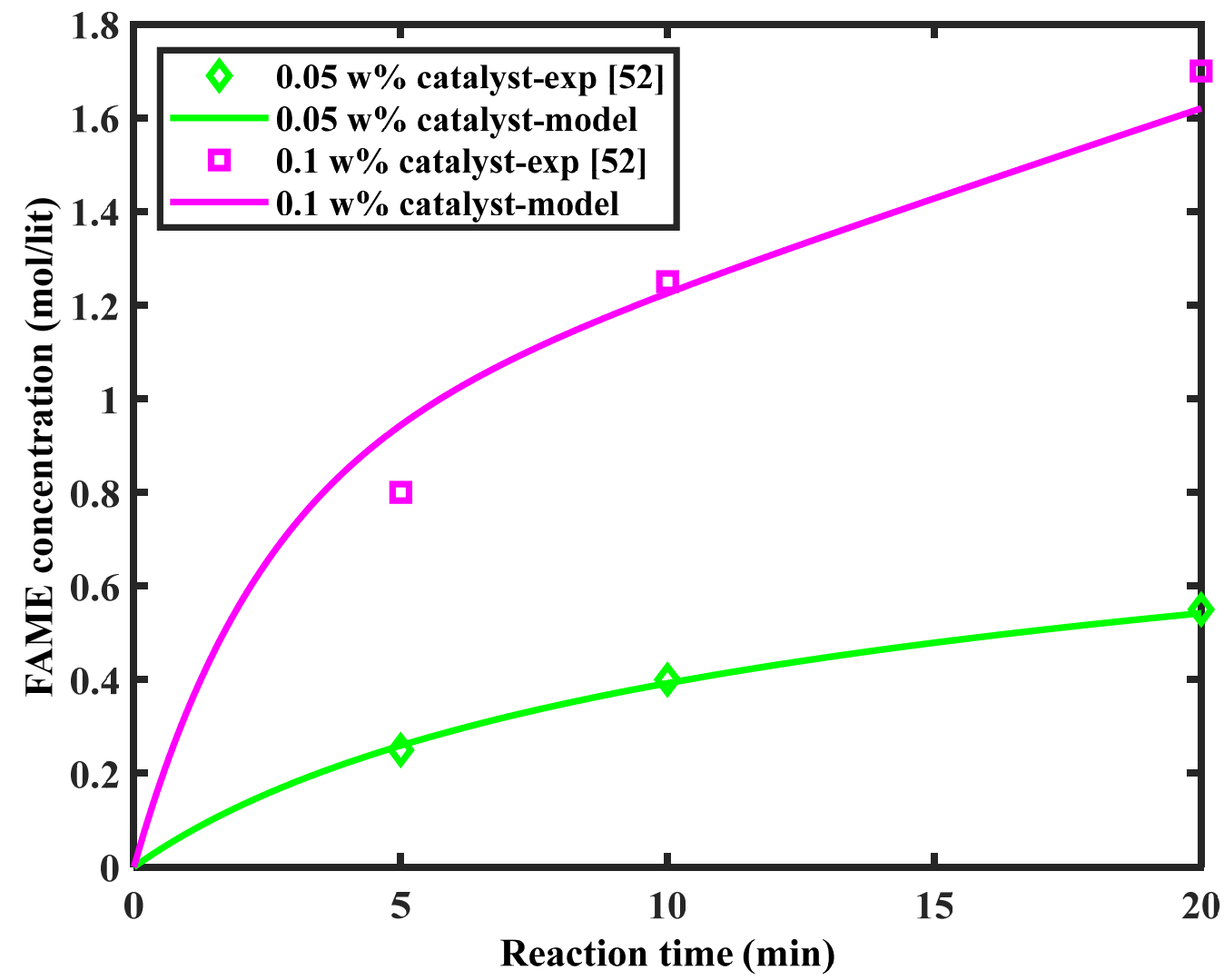

Figure 10. The comparison of experimental and calculated FAME concentration variation in the membrane reactor.

As can be seen in Figure 10, the model has a good capability to predict the FAME concentration in the membrane reactor.

\subsubsection{The Proposed Membrane System for Chicken Feet Biodiesel}

The operating parameters of the proposed membrane system for chicken feet biodiesel are listed in Table 8.

The membrane system performance is evaluated by modeling. Only FAME can permeate through the membrane. Figure 11 shows the TG and FAME concentrations at optimum conditions (frequency $=45 \mathrm{kHz}, \mathrm{M} / \mathrm{O}=12$, and catalyst $\mathrm{wt} \%=1$ ). As can be seen, after $15 \mathrm{~min}$, a significant amount of FAME has been produced, which indicates the 
high efficiency of the proposed membrane system. IT means that the reaction time in the membrane system $(15 \mathrm{~min})$ is six times shorter than the conventional method $(1.5 \mathrm{~h})$.

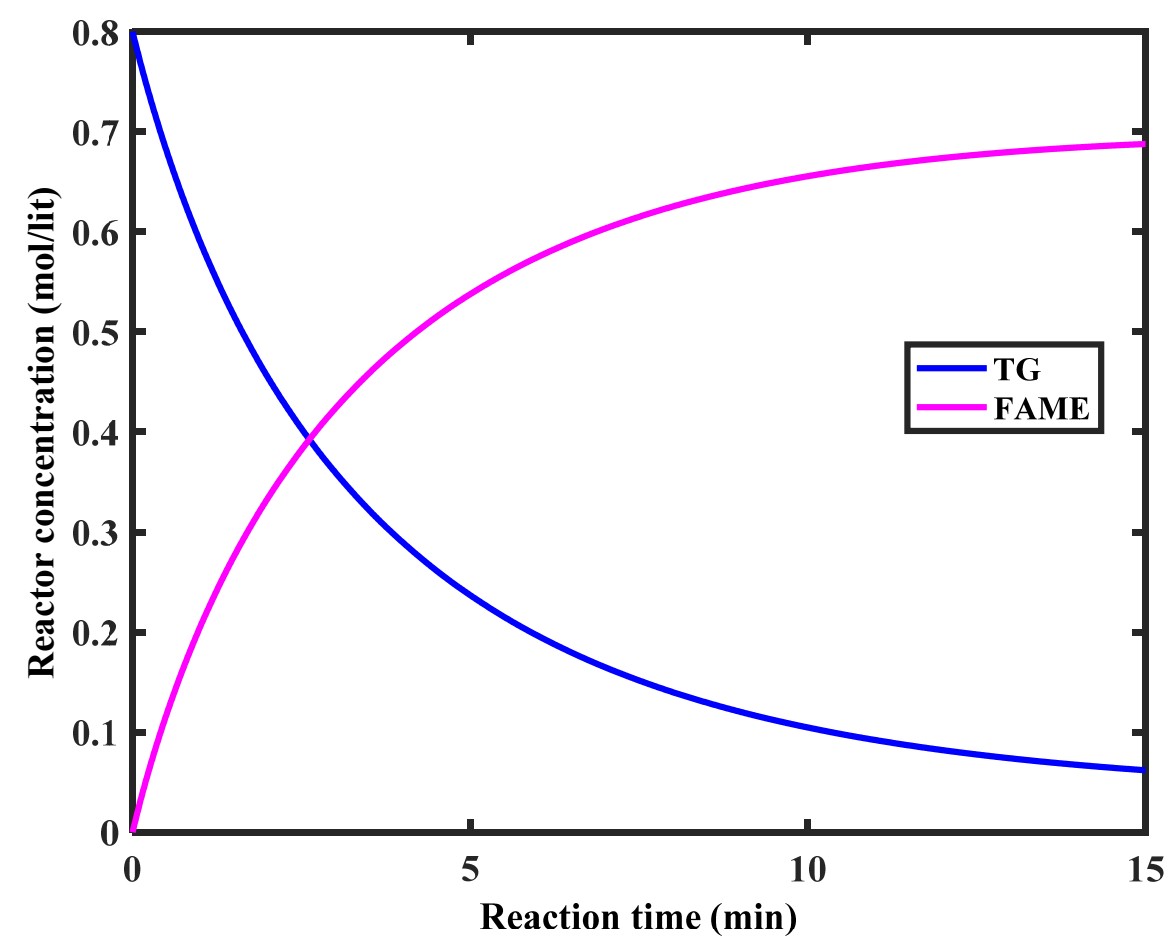

Figure 11. TG and FAME concentrations at reactor outlet, $\mathrm{T}=68^{\circ} \mathrm{C}$, reactor volume $=80$ lit.

The biodiesel yield, as well as TG conversion rates, are shown in Figure 12. A comparison between the biodiesel yield with Figure 8 shows that the proposed system's yield is equivalent to a single batch reactor with a reaction time of $1.5 \mathrm{~h}$. Therefore, the membrane system has significantly improved the reaction rate.

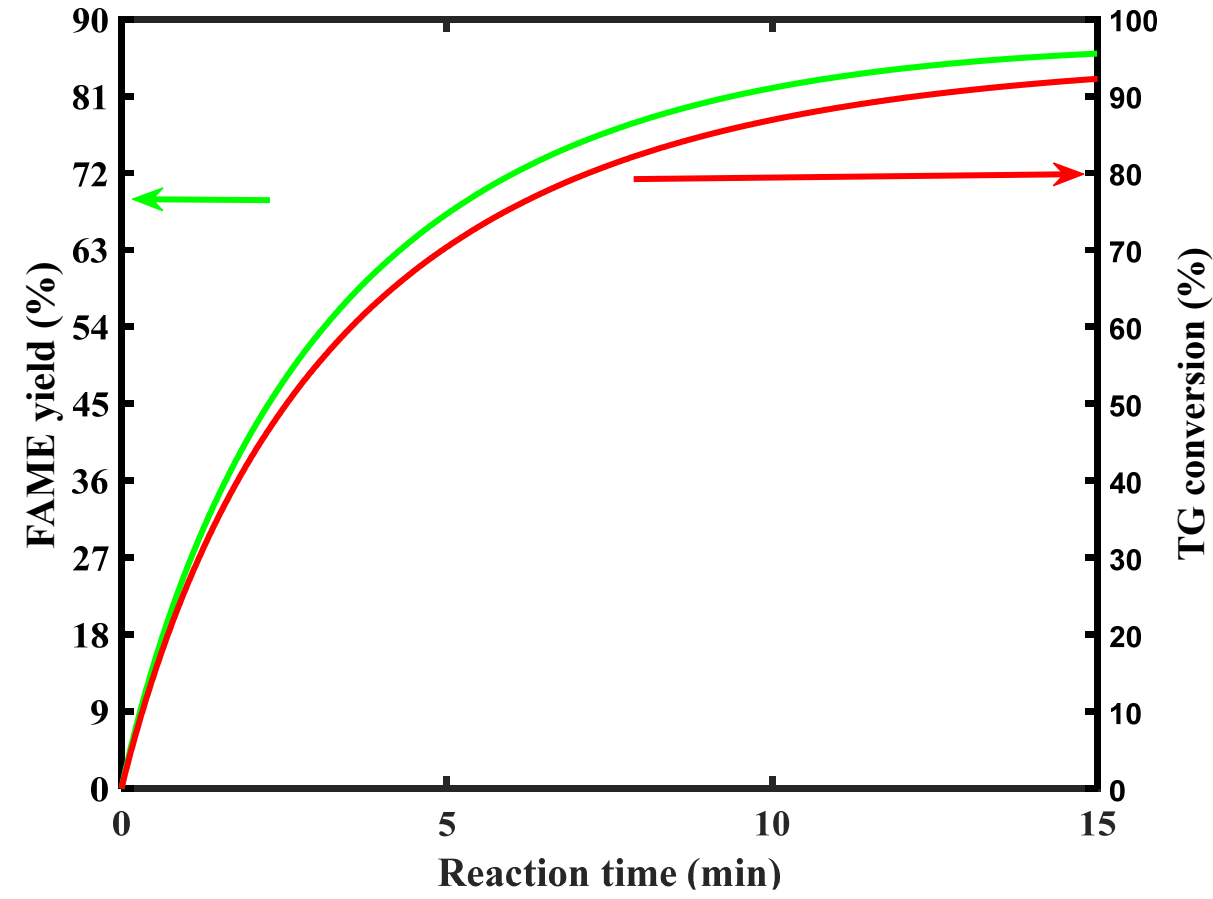

Figure 12. TG conversion and FAME yield. 
The effect of frequency on the reaction yield for the membrane system is shown in Figure 13. As can be seen, at higher frequencies, we would expect a larger effect of membrane application on the biodiesel yield and reaction rate.

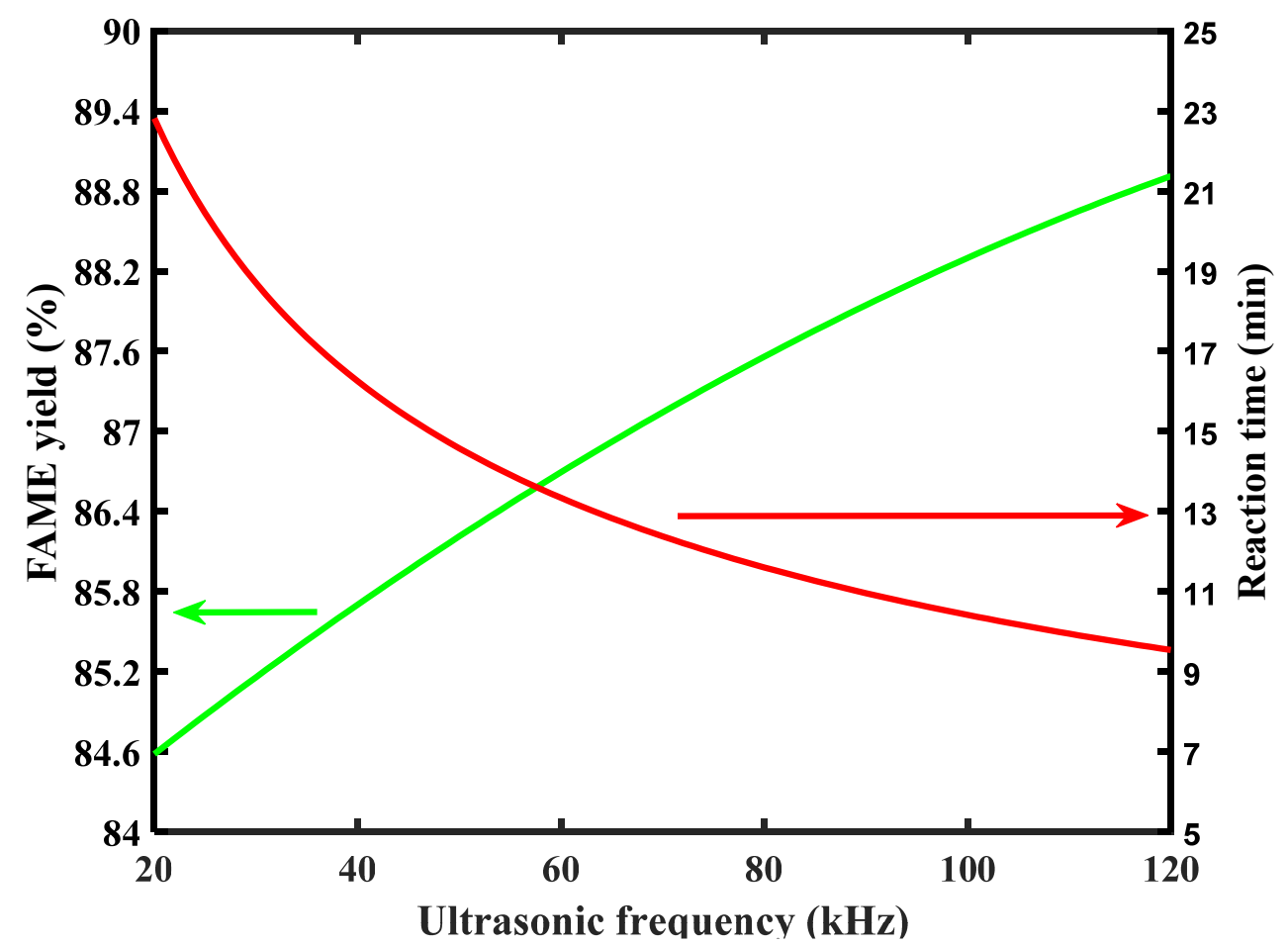

Figure 13. The effect of frequency on the reaction yield for the membrane system.

\section{Conclusions}

Due to the energy crisis and the declining fossil fuel reserves, researchers have been interested in biodiesel as an alternative fuel. In this study, an experimental setup was designed to generate biodiesel from chicken feet oil using ultrasonic waves with two frequencies ( 25 and $45 \mathrm{kHz}$ ). The chicken feet oil was subjected to the esterificationtransesterification processes. The effect of $\mathrm{M} / \mathrm{O}$ molar ratio and $\mathrm{KOH}$ catalyst amount on biodiesel yield was investigated. A polynomial model obtained by RSM analyzed the experimental data.

The desirability function approach found the optimized conditions. Results showed that the highest biodiesel yield could be achieved using a methanol-to-oil ratio of 12, the $\mathrm{KOH}$ amount of $1 \mathrm{wt} \%$, and the ultrasonic sound frequency of $45 \mathrm{kHz}$. The predicted yield $(89.74 \%)$ was in good agreement with the experimental yield $(90.14 \%)$.

Finally, the biodiesel was analyzed to evaluate the biodiesel characteristics as a fuel. The analysis of density, acid value, saponification value, iodine value, kinematic viscosity, and combustion properties showed the good performance of chicken feet oil biodiesel compared to other fuels.

In this study, a membrane system is proposed to decrease the time consumption of the process. The mathematical modeling results showed the reaction time appears to be six times shorter in a membrane setup. The membrane effect is more prominent at greater frequencies than the lower ones. Consequently, membrane application is highly recommended for biodiesel production.

Author Contributions: Conceptualization, S.M.J. and P.P.; methodology, P.P., S.M.J.; software, S.F.M.H.; validation, S.M.J., P.P. and S.F.M.H.; formal analysis, A.B.; investigation, S.M.J., P.P. and A.B.; resources, S.F.M.H.; data curation, A.B.; writing—original draft preparation, S.M.J.; writing—review and editing, A.B.; visualization, P.P. All authors have read and agreed to the published version of the manuscript. 
Acknowledgments: The authors would like to express their gratitude to the Iran National Science Foundation (INSF) for supporting this work.

Conflicts of Interest: The authors declare that there is no conflict of interest.

\section{References}

1. Ardebili, M.S.; Ghobadian, B.; Najafi, G.; Chegeni, A. Biodiesel production potential from edible oil seeds in Iran. Renew. Sustain. Energy Rev. 2011, 15, 3041-3044. [CrossRef]

2. Ghorbani, A.; Rahimpour, M.R.; Ghasemi, Y.; Raeissi, S. The Biodiesel of Microalgae as a Solution for Diesel Demand in Iran. Energies 2018, 11, 950. [CrossRef]

3. Bazooyar, B.; Darabkhani, H.G. Design and numerical analysis of a $3 \mathrm{kWe}$ flameless microturbine combustor for hydrogen fuel Int. J. Hydrogen Energy 2019, 44, 11134-11144. [CrossRef]

4. Bagnato, G.; Sanna, A. Process and Techno-Economic Analysis for Fuel and Chemical Production by Hydrodeoxygenation of Bio-Oil. Catalysts 2019, 9, 1021. [CrossRef]

5. Jian-Xun, W.; Huang, Q.D.; Huang, F.H.; Huang, Q.J. Lipase-catalyzed production of biodiesel from high acid value waste oil using ultrasonic assistant. Chin. J. Biotechnol. 2007, 23, 1121-1128. [CrossRef]

6. Roosta, A.; Bardool, R. A Predictive Correlation for Dynamic Viscosity of Fatty Acid Methyl Esters and Biodiesel. J. Am. Oil Chem. Soc. 2019, 96, 741-750. [CrossRef]

7. Bhatti, H.N.; Hanif, M.A.; Qasim, M. Biodiesel production from waste tallow. Fuel 2008, 87, 2961-2966. [CrossRef]

8. Alptekin, E.; Canakci, M. Optimization of pretreatment reaction for methyl ester production from chicken fat. Fuel 2010, 89 , 4035-4039. [CrossRef]

9. Van Gerpen, J. Biodiesel processing and production. Fuel Process. Technol. 2005, 86, 1097-1107. [CrossRef]

10. Capote, F.P.; de Castro, M.L. Analytical Applications of Ultrasound; Elsevier: Amsterdam, The Netherlands, 2007.

11. Suslick, K.S. The chemical effects of ultrasound. Sci. Am. 1989, 260, 80-87. Available online: https://www.jstor.org/stable/2498 7145 (accessed on 1 February 1989). [CrossRef]

12. Ghavami, S.; Gregory, A.; Webb, J.; Bayat, M.; Denis, M.; Kumar, V.; Milbrand, T.A.; Larson, A.N.; Fatemi, M.; Alizad, A. Ultrasound Radiation Force for the Assessment of Bone Fracture Healing in Children: An In Vivo Pilot Study. Sensors 2019, 19, 955. [CrossRef]

13. Tagliapietra, S.; Gaudino, E.C.; Cravotto, G. The use of power ultrasound for organic synthesis in green chemistry. In Power Ultrasonics; Elsevier: Amsterdam, The Netherlands, 2015; pp. 997-1022. [CrossRef]

14. Maddikeri, G.L.; Gogate, P.R.; Pandit, A.B. Intensified synthesis of biodiesel using hydrodynamic cavitation reactors based on the interesterification of waste cooking oil. Fuel 2014, 137, 285-292. [CrossRef]

15. Stavarache, C.; Vinatoru, M.; Nishimura, R.; Maeda, Y. Conversion of vegetable oil to biodiesel using ultrasonic irradiation. Chem. Lett. 2003, 32, 716-717. [CrossRef]

16. Bastante, J.S.; Ortega-Román, C.; Pinzi, S.; Lara-Raya, F.R.; Leiva-Candia, D.E.; Dorado, M.P. Ultrasound-Assisted Biodiesel Production from Camelina sativa oil. Bioresour. Technol. 2015, 185, 116-124. [CrossRef]

17. Van Gerpen, J.; Shanks, B.; Pruzsko, R.; Clements, D.; Knothe, G. Biodiesel Production Technology; National Renewable Laboratory: Golden, CO, USA, 2004.

18. Kulkarni, M.G.; Dalai, A.K. Waste cooking oil an economical source for biodiesel a review. Ind. Eng. Chem. Res. 2006, 45, 2901-2913. [CrossRef]

19. Kelkar, M.A.; Gogate, P.R.; Pandit, A.B. Intensification of esterification of acids for synthesis of biodiesel using acoustic and hydrodynamic cavitation. Ultrason. Sonochem. 2008, 15, 188-194. [CrossRef] [PubMed]

20. Teixeira, L.S.; Assis, J.C.; Mendonça, D.R.; Santos, I.T.; Guimaraes, P.R.; Pontes, L.A.; Teixeira, J.S. Comparison between conventional and ultrasonic preparation of beef tallow biodiesel. Fuel Process. Technol. 2009, 90, 1164-1166. [CrossRef]

21. Santos, F.F.; Matos, L.J.; Rodrigues, S.; Fernandes, F.A. Optimization of the production of methyl esters from soybean waste oil applying ultrasound technology. Energy Fuels 2009, 23, 4116-4120. [CrossRef]

22. Santos, F.F.; Malveira, J.Q.; Cruz, M.G.; Fernandes, F.A. Production of biodiesel by ultrasound assisted esterification of Oreochromis niloticus oil. Fuel 2010, 89, 275-279. [CrossRef]

23. Yin, X.; Duan, X.; You, Q.; Dai, C.; Tan, Z.; Zhu, X. Biodiesel production from soybean oil deodorizer distillate using calcined duck eggshell as catalyst. Energy Convers. Manag. 2016, 112, 199-207. [CrossRef]

24. Singh, A.; Pal, A.; Maji, S. Biodiesel production from microalgae oil through conventional and ultrasonic methods, Energy Sources, Part A: Recovery. Util. Environ. Eff. 2017, 39, 806-810. [CrossRef]

25. Suryanto, A.; Sabara, H.Z.; Ismail, H.; Artiningsih, A.; Zainuddin, U.; Almukmin, A.; Nurichsan, U.; Niswah, F. Production Biodiesel from Kapok Seed Oil Using Ultrasonic. In IOP Conference Series: Earth and Environmental Science; IOP Publishing: Saint Petersburg, Russia, 2018; pp. 12-23.

26. Rabu, R.A.; Janajreh, I.; Honnery, D. Transesterification of waste cooking oil: Process optimization and conversion rate evaluation. Energy Convers. Manag. 2013, 65, 764-769. [CrossRef]

27. Rashid, U.; Anwar, F. Production of biodiesel through optimized alkaline-catalyzed transesterification of rapeseed oil. Fuel 2008, 87, 265-273. [CrossRef] 
28. Sivakumar, P.; Sindhanaiselvan, S.; Gandhi, N.N.; Devi, S.S.; Renganathan, S. Optimization and kinetic studies on biodiesel production from underutilized ceiba pentandra oil. Fuel 2013, 103, 693-698. [CrossRef]

29. Gole, V.L.; Gogate, P.R. Intensification of synthesis of biodiesel from non-edible oil using sequential combination of microwave and ultrasound. Fuel Process. Technol. 2013, 106, 62-69. [CrossRef]

30. Choudhury, H.A.; Goswami, P.P.; Malani, R.S.; Moholkar, V.S. Ultrasonic biodiesel synthesis from crude Jatropha curcas oil with heterogeneous base catalyst: Mechanistic insight and statistical optimization. Ultrason. Sonochem. 2014, 21, 1050-1064. [CrossRef]

31. Canoira, L.; Gamero, M.R.; Querol, E.; Alcantara, R.; Lapuerta, M.; Oliva, F. Biodiesel from low-grade animal fat: Production process assessment and biodiesel properties characterization. Ind. Eng. Chem. Res. 2008, 47, 7997-8004. [CrossRef]

32. Abid, M.; Touzani, A.; Benhima, R. Synthesis of biodiesel from chicken's skin waste by homogeneous transesterification. Int. J. Sustain. Eng. 2019, 12, 272-280. [CrossRef]

33. Fangrui, M.; Milford, A.H. Biodiesel production: A review. Bioresour. Technol. 1999, 70, 1-15. [CrossRef]

34. Demirbas, A. Biodiesel; Springer: London, UK, 2008; pp. 111-119.

35. Othmana, R.; Mohammad, A.W.; Ismail, M.; Salimon, J. Application of polymeric solvent resistant nanofiltration membranes for biodiesel production. J. Membr. Sci. 2010, 348, 287-297. [CrossRef]

36. Shuit, S.H.; Ong, Y.T.; Lee, K.T.; Subhash, B.; Tan, S.H. Membrane technology as a promising alternative in biodiesel production: A review. Biotechnol. Adv. 2012, 30, 1364-1380. [CrossRef]

37. Sokac, T.; Gojun, M.; Tusek, A.J.; Salic, A.; Zelic, B. Purification of biodiesel produced by lipase catalysed transesterification by ultrafiltration: Selection of membranes and analysis of membrane blocking mechanisms. Renew. Energy 2020, 159, 642-651. [CrossRef]

38. Ghasemzadeh, K.; Amiri, Y.Y.; Zeynali, R. Basile. In Current Trends and Future Developments on (Bio-) Membranes, 1st ed.; Elsevier: Amsterdam, The Netherlands, 2020; Chapter 4; p. 92.

39. Naderi, A.; Chung, T.S.; Weber, M.; Maletzko, C. High performance dual-layer hollow fiber membrane of sulfonated polyphenylsulfone/Polybenzimidazole for hydrogen purification. Membr. Sci. 2019, 591, 117292. [CrossRef]

40. Zito, P.F.; Brunetti, A.; Barbieri, G. Selective Mass Transport of $\mathrm{CO}_{2}$ Containing Mixtures through Zeolite Membranes. Membr. Sci. Res. 2020, 6, 333-343. [CrossRef]

41. Gilani, N.; Towfighi, J.; Rashidi, A.; Mohammadi, T.; Omidkhah, M.R.; Sadeghian, A. Investigation of H2S separation from $\mathrm{H} 2 \mathrm{~S} / \mathrm{CH} 4$ mixtures using functionalized and non-functionalized vertically aligned carbon nanotube membranes. Appl. Surf. Sci. 2013, 270, 115-123. [CrossRef]

42. Chatterjee, G.; Houde, A.A.; Stern, S.A. Poly(ether urethane) and poly(ether urethane urea) membranes with high H2S/CH4 selectivity. Membr. Sci. 1997, 135, 99-106. [CrossRef]

43. Alamsyaha, R.; Loebisa, E.H. Design and technical testing for crude biodiesel reactor using dry methods: Comparison of energy analysis. Energy Procedia 2014, 47, 235-241. [CrossRef]

44. Atadashi, I.M.; Aroua, M.K.; Aziz, A.R.A. Biodiesel separation and purification: A review. Renew. Energy 2011, 36, 437-443. [CrossRef]

45. Atadashi, I.M. Purification of crude biodiesel using dry washing and membrane technologies. Alex. Eng. J. 2015, 14, 383-396. [CrossRef]

46. Alves, M.J.; Nascimento, S.M.; Pereira, I.G.; Martins, M.I.; Cardoso, V.L.; Reis, M. Biodiesel purification using micro and ultrafiltration membranes. Renew. Energy 2013, 58, 15-20. [CrossRef]

47. Noriega, M.A.; Narváez, P.C.; Habert, A.C. Biodiesel separation using ultrafiltration poly(ether sulfone) hollow fiber membranes: Improving biodiesel and glycerol rich phases settling. Chem. Eng. Res. Des. 2018, 138, 32-42. [CrossRef]

48. Noriega, M.A.; Narváez, P.C.; Habert, A.C. Simulation and validation of biodiesel production in Liquid-Liquid Film Reactors integrated with PES hollow fibers membranes. Fuel 2018, 227, 367-378. [CrossRef]

49. Talaghat, M.R.; Jokar, S.M.; Modarres, E. Mathematical modeling of methyl ester concentration distribution in a continuous membrane tubular reactor and comparison with conventional tubular reactor. Heat Mass Transf. 2017, 53, 3099-3108. [CrossRef]

50. Cao, P.; Dube, M.A.; Tremblay, A.Y. Methanol recycling in the production of biodiesel in a membrane reactor. Fuel 2008, 87, 825-833. [CrossRef]

51. Cao, P.; Dube', M.A.; Tremblay, A.Y. High-purity fatty acid methyl ester production from canola, soybean, palm, and yellow grease lipids by means of a membrane reactor. Biomass Bioenergy 2008, 32, 1028-1036. [CrossRef]

52. Cao, P.; Tremblay, A.Y.; Dube, M.A. Kinetics of canola oil transesterification in a membrane reactor. Ind. Eng. Chem. Res. 2009, 48, 2533-2541. [CrossRef]

53. Arteaga, H.; Siche, R.; Pagador, S.; Cáceres, H. Effect of transesterification temperature and time on yield and calorific value of biodiesel from refined fat of chicken. Sci. Agropecu. 2010, 1, 37-45. [CrossRef]

54. Getahun, E.; Getahune, N. Experimental investigation and characterization of biodiesel production from leather industry fleshing Wastes. Renew. Sustain. Energy 2013, 2, 120-129. [CrossRef]

55. Tan, Y.H.; Abdullah, M.O.; Nolasco-Hipolito, C.; Zauzi, N.S.A. Application of RSM and Taguchi methods for optimizing the transesterification of waste cooking oil catalyzed by solid ostrich and chicken-eggshell derived CaO. Renew. Energy 2017, 114, 437-447. [CrossRef]

56. Montgomery, D.C. Design and Analysis of Experiments; John Wiley \& Sons: Hoboken, NJ, USA, 2001; Volume 52, pp. $218-286$. 
57. Rana-Madaria, P.; Nagarajan, M.; Rajapagol, C.; Garg, B.S. Removal of chromium from aqueous solutions by treatment with carbon aerogel electrodes using response surface methodology. Ind. Eng. Chem. Res. 2005, 44, 6549-6559. [CrossRef]

58. Patil, P.D.; Gude, V.G.; Mannarswamy, A.; Deng, S.; Cooke, P.; Munson-McGee, S.; Rhodes, I.; Lammers, P.; Nirmalakhandan, N. Optimization of direct conversion of wet algae to biodiesel under supercritical methanol conditions. Bioresour. Technol. 2011, 102, 118-122. [CrossRef] [PubMed]

59. Grant, G.E.; Gude, V.G. Kinetics of ultrasonic transesterification of waste cooking oil. Sustain. Energy 2014, 33, 1051-1058. [CrossRef] 